\author{
ROMANA OBROCKA \\ (D) https://orcid.org/0000-0002-9663-415X \\ Fundacja Kultury i Dziedzictwa Ormian Polskich \\ OBORNIKI ŚLĄSKIE
}

\title{
LISTY Z ŁAGRU ISSAKA ANTONIEGO DONIGIEWICZA
}

Od 8 czerwca 1941 roku, którą to datę nosi ostatni list napisany przez Issaka Antoniego Donigiewicza - bankowca, restauratora, społecznika, konspiratora, zesłańca ${ }^{1}$ - minęło 78 lat. Odszedł ich autor, odeszli już też adresaci. Następne, żyjące pokolenia noszą w sobie pamięć tamtego czasu i wydarzeń. Mglistą pamięć, ale wciąż przechowywaną. W latach 2012 i 2014 miałam zaszczyt rozmawiać z panią Teresą Płytyczową, córką Issaka Donigiewicza. Udzieliła mi wielu informacji o rodzinach Donigiewiczów, Ohanowiczów i innych, udostępniła bogate archiwum fotograficzne oraz listy swego ojca². Nadmieniła o nieudanej próbie opublikowania drukiem tych listów, co było życzeniem także jej siostry, Marii. Kopie listów w formie zdygitalizowanej, jak i pozostałą część rodzinnego archiwum, Jakub Płytycz - prawnuk Issaka Donigiewicza - przekazał do zbiorów Fundacji Kultury i Dziedzictwa Ormian Polskich w Warszawie. On też, wraz z matką Ireną Płytyczową, służył pomocą w rozwikłaniu niejasności przy niniejszej edycji listów.

Autor listów - Issak Donigiewicz, przez bliskich zwany zdrobniale Sianio urodził się 4 grudnia 1891 roku w Tarnawie (Tyrnawie) na Bukowinie (obecnie Rumunia). Był synem Teodora i Anny z Wartanowiczów, bratankiem Dominika

${ }^{1}$ O Issaku Donigiewiczu pisałam na łamach czasopisma „Awedis”: R. Obrocka, Issak Antoni Donigiewicz, „Awedis”, 18, 2014, s. 10 (wersja internetowa: http://wiki.ormianie.pl/ index.php?title=Issak_Antoni_Donigiewicz\&redirect=no). Zob. też: S. Nicieja, Kresowa Atlantyda. Historia i mitologia miast kresowych, 6, Stryj, Kuty, Rybno, Baniłów, Kniaże, Zatucze, Opole 2015, s. 204-206.

2 O niej zob.: B. S. Kasprowicz, Teresa z Donigiewiczów Płytyczowa, „Awedis”, 21, 2014, s. 9. 
i Jakuba Donigiewiczów. Rodzina Donigiewiczów wywodziła się z Kut, gdzie urodził się dziad Issaka, Antoni (2 lutego 1830 roku), żonaty z Anną z Bohosiewiczów. Issak węzłem małżeńskim związał się z panną Anną Ohanowiczówną z Drohobycza, córką Jana i Marii z Janowiczów (rodzonej siostry „Pietruni” Donigiewiczowej, właścicielki słynnego kuckiego pensjonatu Zacisze przy ul. Ormiańskiej 10). Ich związek małżeński pobłogosławił 20 kwietnia 1926 roku arcybiskup Józef Teodorowicz w katedrze ormiańskiej we Lwowie. Młodzi małżonkowie zamieszkali w Kutach przy ul. Zielonej 6, w połówce domu, po sąsiedzku z rodziną Agopsowiczów. Doczekali się dwóch córek: Teresy, urodzonej 7 maja 1927 roku, i Marii, urodzonej równo w cztery lata później, 7 maja 1931 roku - zdrobniale zwanych „Rysieńką” i „Myszką”. W tym szczęśliwym stadle „Pan Tato” do „Pani Mamy” zwracał się per „Duszko”, „Duszyczko”, a dziewczynki do rodziców mówiły nie inaczej, jak tylko „mamusiu” i „tatusiu”. Issak miał jednego brata, Antoniego ( $\uparrow 1946)$, w rodzinie zwanego „Tolem”, który mieszkał w Stanisławowie. Był kapitanem Wojska Polskiego i ożenił się z Zofią Krygowską. Ich jedynym synem był Andrzej. Dla pełnego obrazu kręgu rodzinnego dodać tu jeszcze trzeba, że żona Issaka miała dwóch braci i trzy siostry. Kazimierz i Roman Ohanowiczowie byli inżynierami leśnikami, obaj pracowali w nadleśnictwie Rafajłowa, przy czym Kazimierz w 1938 roku przeniósł się do nadleśnictwa w Kosowie. Siostry to: Maria, Helena i przysposobiona Wisia Ohanowiczówne.

Dom Donigiewiczów w Kutach dobrze utrwalił się w pamięci rodzinnej. „Od furtki do schodków domostwa przy ul. Zielonej 6 prowadziła ścieżka, po obu stronach obsadzona krzewami czerwonej porzeczki. Pod oknami rosły dalie i krzewiły się róże i bzy, których zapach oknami wnikał do wewnątrz" - z rozrzewnieniem wspominała w 2012 roku Teresa Płytyczowa.

W okolicach spiżarni roznosił się zapach wędlin, które po przyprawieniu według ormiańskiej receptury wędziła na zimno w swoim kurnym domu Ormianka, Karsunecha. Oczami duszy rodzinny dom widzę do dziś, zawieszony kilimami i obrazami. Na wypoczynek, ale też dla szukania natchnienia, do Kut zjeżdżali artyści. Jednym z nich był Kazimierz Kostynowicz ze Lwowa. Przyjaźnił się z ojcem. Wielki portret ojca jego autorstwa - w dosyć żartobliwej konwencji - wisiał w naszym holu. Tato pręży na nim muskuły. To było odniesienie do funkcji, jaką pełnił w „Sokole": prowadził kuckie Towarzystwo Gimnastyczne «Sokół» od jego powołania aż do wojny. Z kolei bliską przyjaciółką mamy była malarka, [Olga] Plutecka-Saloni. Kuckie pejzaże jej pędzla zdobią moje mieszkanie do dziś. Bardzo chętnie bywaliśmy też w domu Pietruni Donigiewiczowej; z siostrą bywałyśmy tam prawie codziennie. Nęcił nas tamtejszy gwar, liczni goście i atmosfera nieustannej wesołości ${ }^{3}$.

${ }^{3}$ Relacja T. Płytyczowej, uzyskana przez autorkę artykułu 31 lipca 2012 i 15 lutego 2014 roku w Bytomiu. 
Źródłem utrzymania rodziny była państwowa posada Issaka Donigiewicza jako prezesa banku (prawdopodobnie kuckiego oddziału Banku Gospodarstwa Krajowego). Bank i poczta były umieszczone w jednym budynku, który znajdował się po prawej stronie (idąc od Rynku) ul. Kosowskiej, zaraz za budynkiem Szkoły Żeńskiej. Prywatną działalnością Donigiewicza była restauracja Burkut. Kiedy zaczęła dobrze prosperować, zrezygnował z posady bankowej. Restauracja była usytuowana w samym centrum, na rogu ulic Starosadowej oraz Śniatyńskiej, i sąsiadowała z Gospodą Ormiańską Klementyny Janowiczowej na rogu ulic Śniatyńskiej i Kosowskiej. Oboje - „Sianio” i „Klimcia” - prowadzili kuchnie, które serwowały ormiańskie przysmaki: zupy, sery, lody, torty, nugaty, wędliny, o winach nie wspominając. Zaopatrzenie restauracji zapewniał Teodor Donigiewicz, ojciec Issaka, właściciel czy też dzierżawca majątku ziemskiego pod Kutami. Burkut był restauracją całoroczną. Na czas wakacji wyposażano go w letni ogródek z drewnianą podłogą i stolikami wśród piennych róż. Interes nastawiony był na przyjezdnych gości, ale też chętnie bywali tu kuccy obywatele. Biesiadowanie u „Siania” i „Klimci” umilała muzyka, którą na harmonii wykonywał Michał Paradowski.

Oprócz wspomnianego Towarzystwa Gimnastycznego, Issak Donigiewicz udzielał się wszechstronnie w kuckim światku kulturalnym. Anna Stefanowiczowa (siostrzenica Petroneli Donigiewiczowej) w 2012 roku wspominała to tak: „Sianio to był taki mądry i rzutki człowiek, że no! Przeczytał jakąś sztukę teatralną po rosyjsku. Spodobała mu się. Raz, raz, przetłumaczył i już przedstawienie w «Sokole» się szykuje"». Ponadto prowadził szeroką korespondencję. Miał rozległe kontakty zawodowe i towarzyskie.

Prawie w każdym kuckim wspomnieniu pojawia się wątek związany ze śmiercią pisarza Tadeusza Dołęgi-Mostowicza, który został postrzelony przez sowieckiego żołnierza w czasie zajmowania Kut przez Armię Czerwoną 20 września 1939 roku. W pochówku pisarza kluczową rolę odegrała rodzina Donigiewiczów.

Utworzyło się nieformalne towarzystwo polskie - wspominała Teresa Płytyczowa - aby zorganizować godny pochówek Mostowicza. Przyszli oni do rodziców, bo jeszcze przed wojną tato wybudował grobowiec dla rodziny na sześć miejsc. W nim była pochowana na razie tylko babcia, Maria z Janowiczów Ohanowiczowa. Ojciec zgodził się, aby Mostowicza pochować w rodzinnym grobowcu, bez tabliczki, tymczasowo, bo przecież zaraz na pewno rodzina zechce przetransportować szczątki na stałe miejsce pochówku. A ponadto było przekonanie, że to wojenne zamieszanie zaraz się skończy. Ojciec przez swoje kontakty zawiadomił listownie (list podał przez żołnierza wracającego do Warszawy) brata Mostowicza

${ }^{4}$ Relacja A. Stefanowiczowej, uzyskana przez autorkę artykułu 11 kwietnia 2012 roku w Gorlicach. 
o śmierci i miejscu pochówku. Brat podjął starania o ekshumację, ale Rosjanie nie wyrazili zgody. Już mocno po wojnie rzemieślnik wykuł mnie tablicę na grób z informacją, że pochowani są Tadeusz Dołęga-Mostowicz i babcia Maria z Janowiczów Ohanowiczowa. Tę tablicę zawiozłyśmy z siostrą Marią do Kut. A po jakimś czasie słyszę w radiu, że na Powązkach jest pogrzeb Mostowicza 5 . W sprawie o wyrażenie zgody na ekshumację interweniował aż prymas Stefan Wyszyński ${ }^{6}$.

Ta opowieść prostuje dane, jakie na ten temat podawano dotychczas ${ }^{7}$.

Przy prospołecznym podejściu do życia było niemożliwe, aby po wybuchu wojny Issak Donigiewicz nie uaktywnił się w konspiracyjnej działalności. Jednym z pilnych zadań było współorganizowanie siatki przerzutowej dla uciekinierów z okupowanego przez Związek Sowiecki kraju do Rumunii, i dalej na Zachód.

Wiem, że w sprawę wtajemniczone były trzy osoby: wuj Kazimierz, leśnik, w Kosowie (w konspiracji była także sekretarka z nadleśnictwa, też aresztowana przez NKWD), a tato w Kutach - opowiadała Teresa Płytyczowa - i jeszcze jedna osoba, której nazwiska nie pamiętam. Osoba, którą trzeba było przerzucić, przyjeżdżała ze Lwowa do Kosowa, do wuja do nadleśnictwa i tam nocowała. Kręciło się tam wiele osób, więc ruch mógł nie budzić podejrzeń. Potem przyjeżdżała do nas. Rodzice ukrywali ją w stodole. Jedzenie do stodoły nosiła moja młodsza siostra, wówczas ośmioletnia. Kręcące się po podwórku dziecko też nie budziło podejrzeń. To znaczy my, jako dzieci, wiedziałyśmy wszystko, ale nic nie mówiłyśmy. Wieczorem przychodził właśnie ten ktoś i pod osłoną nocy przeprowadzał uciekiniera przez Czeremosz na rumuńską stronę. Z rozmów dorosłych utkwiło mi w głowie, że jest to ktoś, kto doskonale zna niewidoczne przesmyki w łęgach nad rzeką i płycizny Czeremoszu. A ponadto znał czas zmian warty sowieckich pograniczników, kiedy jeden schodził z warty, a drugi jeszcze nie przyszedł. Teraz myślę, że mógł to być ktoś, kto „zawodowo” zajmował się przemytem ${ }^{8}$.

5 Prochy Mostowicza zostały złożone w katakumbach cmentarza Powązkowskiego w Warszawie 24 listopada 1978 roku.

${ }^{6}$ Relacja T. Płytyczowej, uzyskana przez autorkę artykułu 31 lipca 2012 i 15 lutego 2014 roku w Bytomiu.

${ }^{7}$ Np. w życiorysie zamieszczonym w Polskim słowniku biograficznym czytamy, że Mostowicz ,został pochowany w grobowcu rodziny Manugiewiczów” (J. B akan acz, Mostowicz (Dołega-Mostowicz) Tadeusz, w: Polski słownik biograficzny, 22, Warszawa-Wrocław-Kraków-Gdańsk 1977, s. 62). Poprawne dane na temat miejsca kuckiego pochówku zawarł w powieści Ukraiński kochanek Stanisław Srokowski, posiłkując się relacjami dawnych mieszkańców Kut.

8 Relacja T. Płytyczowej, uzyskana przez autorkę artykułu 31 lipca 2012 i 15 lutego 2014 roku w Bytomiu. 
Zdarzyło się jednak nieszczęście. W maju 1940 roku przy próbie przeprawy przez Czeremosz został zastrzelony przez sowieckich pograniczników ks. Bogdan Agopsowicz, wikariusz katedry ormiańskiej we Lwowie, redaktor podziemnego czasopisma „Pobudka”, który pomagał polskim żołnierzom w przekraczaniu granicy z Rumunią, korzystając ze wsparcia rodzin ormiańskich w swych rodzinnych Kutach ${ }^{9}$. Potwierdza ten fakt Teresa Płytyczowa: „Wiem, że wcześniej też [ks. Agopsowicz] był zaangażowany w organizację przerzutów. I posypały się aresztowania. Już w maju ojciec został aresztowany przez NKWD. Wuj Kazimierz - w lipcu. Ojciec został zesłany do łagru Iwdel w swierdłowskiej obłasti na Uralu - z pięcioletnim wyrokiem. A wuj Kazimierz nie przeżył więzienia w Stanisławowie. Podobno przez enkawudzistów został żywcem zamurowany ${ }^{10}{ }^{11}$.

Sądząc po wzmiankach w listach, Issak Donigiewicz ze Lwowa, zanim trafił do Iwdela, został przewieziony do więzień NKWD w Charkowie (przy pl. Dzierżyńskiego 3) i Melitopolu (nie wiadomo w jakiej kolejności). W Charkowie w kwietniu i maju 1940 roku NKWD zamordowało ok. 3800 więźniów z obozu w Starobielsku. Autor listów był tam więziony niedługo potem, co najmniej do grudnia 1940 roku. W łagrze iwdelskim znalazł się także Wiesław Wolfowicz, oficer WP, który został aresztowany przez NKWD, gdy usiłował przedostać się na Zachód w lutym 1940 roku. Przeszedł więzienie we Lwowie i - podobnie jak Issak Donigiewicz - został skazany na karę pięciu lat pozbawienia wolności. Jednak on z Iwdela został zwolniony na mocy układu Sikorski-Majski z 30 lipca 1941 roku $^{12}$, podobnie jak inni jeszcze więźniowie, np. literat Paweł Hertz.

Issak Donigiewicz nie znalazł się wśród zwolnionych na mocy wspomnianego układu. Ostatnia udokumentowana wiadomość o jego losach pochodzi z 8 czerwca 1941 roku, czyli z okresu na kilka tygodni przed atakiem Niemiec na Związek Sowiecki (22 czerwca). Był wtedy w grupie więźniów, którzy oczekiwali w punkcie przesiedleniowym w przysiółku Jekateryninka pod Iwdelem, dwa kilometry od stacji kolejowej Łangur, na transport w nowe miejsce uwięzienia. Błyskawiczna ofensywa wojsk niemieckich, w trakcie której wschodnie terytoria Polski okupowane od września 1939 roku przez Sowietów dostały się

9 T. Zaleski, Stownik biograficzny księży ormiańskich i pochodzenia ormiańskiego w Polsce w latach 1750-2000, Kraków 2001, s. 24; R. Dzwonkowski, Leksykon duchowieństwa polskiego represjonowanego w ZSRS 1939-1988, Lublin 2003, s. 99.

10 Por.: Zbrodnicza ewakuacja więzień i aresztów NKWD na Kresach Wschodnich II Rzeczypospolitej w czerwcu-lipcu 1941 roku. Materiaty z sesji naukowej w 55. rocznice ewakuacji więźniów NKWD w głąb ZSRR, Łódź, 10 czerwca 1996 r., red. J. Mikoda, Warszawa 1997, s. 31-39. Na temat przemytu ludzi przez Czeremosz i o sytuacji na Pokuciu pod okupacją zob. szerzej: G. Mazur, Pokucie w latach drugiej wojny światowej. Położenie ludności, polityka okupantów, działalność podziemia, Kraków 1994.

${ }_{11}$ Relacja T. Płytyczowej, uzyskana przez autorkę artykułu 31 lipca 2012 i 15 lutego 2014 roku w Bytomiu.

12 https://kresy-siberia.org/hot/?nagranie=wiewolw\&lang=pl. 
pod okupację niemiecką, odcięła kontakt między Kutami a kolejnym, nieznanym nam, miejscem pobytu Issaka Donigiewicza w głębi Związku Sowieckiego. Nie wiadomo zresztą, co NKWD zrobiło z więźniami z punktu przesiedleniowego w Jekaterynince. Czy transport w nowe miejsce nastąpił? A może zostali zastrzeleni i pochowani w okolicznym lesie?

Listów Issaka Donigiewicza z łagru iwdelskiego zachowało się dwadzieścia osiem. Tyle dotarło do adresatów, liczonych według dedykowanych nagłówków: „Najdrozsi”, „Kochana Rysieńko i Myszko”, „Dzieciaki”, „Najdroższa Moja Duszyczko”, „Kochany Dziadziu”..., listów pisanych pięknym kaligrafowanym pismem. Są one świadectwem, że ojciec rodziny nie przestał być nim mimo upływu czasu, oddalenia, katorżniczej egzystencji, degradacji zdrowia. Jego myśli zaprzątała troska o rodzinę. Listy przepojone są miłością do żony, córek i dalszych krewnych. Miłością, której nie wygaszają oddalenie i czas. Miłością, w której jest miejsce na najczulsze słowa, kierowanie rodzinnymi sprawami, ale też na napominanie, strofowanie i oczekiwanie rozsądnej pomocy. W ostatnim udokumentowanym półroczu życia ich autora listy od bliskich były dla niego wszystkim. „Nie wyobrażacie sobie nawet jak czekam listów od Was - a jeśli go dostanę - czytam po 10 razy - względnie uczę się na pamięć!" - pisał 12 kwietnia 1941 roku. Dramatem był dla niego brak wiadomości z domu: „Nie wyobrażacie sobie jak czekam na wiadomości z domu, jak uganiam po powrocie $\mathrm{z}$ lasu po biurach za pocztą, a gdy otrzymam odpowiedź negatywną - wprost z płaczem odchodzę do baraku" - czytamy w liście z 12 maja 1941 roku. Ale też dzisiejszego czytelnika, gdy zagłębia się w te rzeczowe i beznamiętne opisy łagierniczej egzystencji, serce boli i dusza płacze.

Listów jest dwadzieścia osiem: z takich tekstów składają się święte księgi. Pierwszy list nosi datę 7 lutego 1941 roku. Ostatni - 8 czerwca 1941 roku. Na tym korespondencja się urywa. Issak Antoni Donigiewicz żył 52 lata, jeżeli wierzyć w datę śmierci 3 lutego 1943 roku - podaną przez Radziecki Czerwony Krzyż w roku 1960. 
Listy $^{13}$

1.

Найдорозеї мої!

Ивдель ${ }^{14}$ 07.02.[19]41

Тепер пишу до Вас з моєго сталого місця. Дня 12.12 виславєм письмо до Вас з Харкова! ${ }^{15}$ Не знаю, письмо одержали, бо від Вас жадної відповіди до сего часу не получив. Того самого дня написалєм до Кайця ${ }^{16} 3$ Ясенова ${ }^{17}$, просивєм єго аби до Вас заглянув і привіз Вам збіжа і картошки. Дня 21 знова писавєм до него просивєм про Вас і щоби мені дещо післав! Не знаю чи він був у Вас? Тепер мої дорозі питаю о найважнійшу справу. Чи есте всі здорові, що робять тато, діти мої, ти дорога моя дружино і Марилька ${ }^{18}$ ? Яко проживаєте і з чого? О тїм всегда думаю і журусь Вами!

Хтівбим знати що роблять: Ромко і де они ${ }^{19}$, Казьо ${ }^{20}$, чи щось писали Тадзьовє, Тосьовє, Куба' ${ }^{21}$, Васцьо, що робять Касуня ${ }^{22}$, Нуся, Ганя, Зань-

13 Adresy spisane z kopert: 1. адрес: Село Ивдель / Сьвердловская Область / Ящик почтовий 232/09 / Доничевич [!] Иссак Теодорович. [Wieś Iwdel / Obwód swierdłowski / Skrzynka pocztowa 232/09 / Donyczewicz [!] Issak Teodorowicz]. 2. Западна Украіна CCCP / Область: Станислав / город-почта: Косів / коло Коломиї / адресат: Оганович Мария / в дому гр. Хадерских / над млинівкою. [Zachodnia Ukraina - ZSRR / Region: Stanisławów / miasto-poczta: Kosów / koło Kołomyi / adresat: Maria Ohanowicz / w domu p. Chaderskich / nad młynówką].

${ }^{14}$ Iwdel - miasto w Rosji, położone u podnóża Uralu Północnego w obwodzie swierdłowskim.

15 Charków - miasto w północno-wschodniej części Ukrainy, do roku 1934 stolica Ukraińskiej Socjalistycznej Republiki Sowieckiej.

${ }^{16}$ Kajcio - prawdopodobnie chodzi o Kajetana Wartanowicza z rodziny matki autora listów. Zginął on z rąk nacjonalistów ukraińskich 24 lutego 1944 roku w Jasieniowie Polnym (pow. Horodenka).

17 Jasieniów Polny - wieś położona tuż przy granicy polsko-rumuńskiej przy linii kolejowej Kołomyja - Stefaneszty, w okresie międzywojennym znajdowała się tu polska stacja graniczna, a właścicielami miejscowej posiadłości ziemskiej była rodzina ormiańsko-polska Krzysztofowiczów.

18 Marylka - Maria Ohanowiczówna (19 grudnia 1907, Kuty - 5 września 1987, Bytom), szwagierka autora listów.

19 Romko, Romkowie - Roman Ohanowicz, szwagier autora listów, inżynier leśnik w Rafajłowej, w 1944 roku wywiózł Annę (żonę „Siania” i ich córki Teresę oraz Marię) z Kut, w których Ormian i Polaków mordowali nacjonaliści ukraińscy, do Tarnobrzega; potem osiedlił się w Krakowie.

${ }^{20}$ Kazio - Kazimierz Ohanowicz (ok. 1900-1941?) - szwagier autora listów, inżynier leśnik.

${ }^{21}$ Kuba - Jakub Agopsowicz (27 lutego 1910, Kuty - 2 stycznia 1957, Bielsko-Biała), brat Anny Łazarowiczowej.

${ }^{22}$ Kasunia - Katarzyna z Nikosiewiczów Agopsowiczowa, mieszkała w Kutach po sąsiedzku z Donigiewiczami przy ul. Zielonej 6; po wojnie osiedliła się w Bielsku-Białej. 
ко, Ганечка, Крисьовє, Кольо ${ }^{23}$, Петруня ${ }^{24}$, Кс. Манько ${ }^{25}$, всїх поздоровіть від мене! А що робять Рудки і Рондяки, чисьто то зужили чи що з ними ся стало? Не тримайте то, чи корову продалиисьте? Чи мешкаєте дальше там? Як $з$ деревом, чи великі там є морози, бо у нас вже було і понад $45 \%$ ! Чувєм що Марилька слабує на серце. Най уважає, бо она є Ваша кормїтелька! Я чуствуюся добре і добре мені тут. Не маю відваги Вас о щось просити. У Занька в бюрку остався мій тютюн, просивби одного і много бумаг курительних і листових з конвертами і марками! Можна нам посилати пересилки по 8 кг. - чоснику і цебулі, хтів бим дістати і одну (місяц?) пересилку! Сало i сухарі, солод, риж більше можна посилати! Хліба не треба! Маленький кружок і риночка алюміннюва также потрібні. Муки кукурудзєнної трохи від Гані яслиби можна. Пишу отій пересилці, але не знаю чи зможете щось мені післати. Хтівбим дуже аби мені щось мої діти упекли і післали.

Чи ходять до школи і єще раз питаю чисьте всі здорові? Нехай кождий до мене щось в лисьті напише і виразно напишїть що посилаєте! Гроші... тилько переказом! Памятайте о тїм, що я мушу і з другими ся поділити, для того треба всюго більше посилати! Один грубший коц (одєжа) і рушник придавби ся мені! У адвоката Фрідмана ${ }^{26}$ відберіть 100 рублів! Рік тому як пожичив. Напишіть мені о всіх знакомих, а найбільше о собі. Чекаю дуже на відомість від Вас! СКОРО!!! Я о Вас думаю без перерви і чекаю коли ся побачемо! Чи діти виросли? Дуже Вас прошу що зможето пішлїть - дайте адресу Казья.

Моцно Вас всїх цілюю по руках і жилаю Вам Всего добра з Новим годом.

Ваш

Сяню ${ }^{27}$

${ }^{23}$ Kolo - Mikołaj Łazarowicz (1911-?), Ormianin polski, mieszkaniec Kut.

${ }^{24}$ Pietrunia, Stryjanka Pietrunia - Petronela Donigiewiczowa, córka Grzegorza Janowicza i Rypsymy z Markiewiczów, siostra Marii, teściowej autora listów, właścicielka pensjonatu Zacisze w Kutach; jej mężem był prawdopodobnie stryj autora listów; zamordowana w 1944 roku przez ukraińskich nacjonalistów.

${ }^{25}$ Ks. Mańko - prawdopodobnie chodzi o ks. Samuela Manugiewicza (18 maja 1871, Kuty - 28 grudnia 1956, Kuty), proboszcza ormiańskokatolickiego w Kutach, senatora RP (1928), burmistrza Kut (1938), honorowego obywatela tego miasta, w czasie wojny zaangażowanego w pomoc żołnierzom polskim przedostającym się przez Rumunię do Francji; przetrwał mordy dokonywane przez nacjonalistów ukraińskich i sprawował posługę duszpasterską w Kutach aż do śmierci.

26 Adwokat Fridman, Friedmann - Juliusz Friedmann, adwokat kucki.

${ }^{27}$ List napisany został w mieszaninie języka ukraińskiego, rosyjskiego i polskiego. Tłumaczenie na język polski Doroty Lutek: Iwdel 07.02.[19]41. Moi najdrożsi! Teraz piszę do Was z mojego stałego miejsca. W dniu 12.12 wysłałem do Was list z Charkowa! Nie wiem, czy list dotarł, ponieważ nie otrzymałem od Was do tego czasu żadnej odpowiedzi. Napisałem tego samego dnia do Kajcia z Jasionowa - poprosiłem go, aby zajrzał do Was i przywiózł Wam zboże i ziemniaki. Dnia 21 ponownie napisałem do niego, pytając o Was i żeby mi coś 


\section{Najdrozsi!}

Już trzeci raz piszę do Was - nie wiem czyście tamte listy dostali? Zapytuję Was przede wszystkiem o zdrowie, co robi Tato ${ }^{28}$, Ty Anko ${ }^{29}$, Marylka i dzieci, czyście zdrowi, jak żyjecie i z czego? Martwię się bardzo Wami i o Was tylko myślę. Anko wyzbywaj się wszystko co jest - by tylko żyć!

Czy krowa sprzedana, a co zrobiliście ze świnkami? Co słychać w Kutach co robi Ks. Mańko, Krzysiowie, Kolowie ${ }^{30}$, Hania, co ciocia Pietrunia i w ogóle wszyscy krewni i znajomi, co Kasunia, Nusia, Ciuba i inni. Haneczka i Zańkowie, wszystkich odemnie pozdrówcie. Oj-joj! - kiedy się zobaczymy i t.d. i t.d. Napiszcie o sobie dużo - niech Kaziu pisze z osobna - chcę mieć Wasze pismo przed oczyma! Co z Romkami, Tolkami ${ }^{31}$, Tadziami, czy Kazio coś pisał (i skąd)?

wysłał! Nie wiem, czy on był u Was? Teraz moi drodzy pytam o najważniejsze. Czy jesteście zdrowi, co robi mój ojciec, moje dzieci, ty moja droga żono i Marylka? Jak żyjecie i z czego? Zawsze o tym myślę i boję się o Was! Chciałbym wiedzieć, co robią: Romko i gdzie są, Kazio, czy coś pisali Tadziowie, Tosiowie, Kuba, Wasio, co robią Kasunia, Nusia, Hania, Zańko, Haneczka, Krzysiowie, Kolo, Pietrunia, Ks. Mańko, wszystkich ode mnie pozdrówcie! Co robią Rudki i Rondaki, czy coś stracili, czy coś się z nimi stało? Nie ukrywajcie tego, czy krowę sprzedaliście? Czy mieszkacie tam dalej? Jak z drzewem, czy są duże mrozy, ponieważ mieliśmy już ponad 45! Słyszałem, że Marylka ma słabe serce. Niech uważa, ponieważ jest Waszą karmicielką! Czuję się dobrze i jest mi tu dobrze. Nie mam odwagi Was o coś poprosić. U Zańka w biurku został mój tytoń, prosiłbym o jeden i dużo bibułek papierosowych i kartek papieru listowego z kopertami i znaczkami! Można nam wysłać przesyłkę do $8 \mathrm{~kg}$. Czosnek i cebulę chciałbym dostać i jedną (na miesiąc?) przesyłkę! Słoninę i suchary, słód, ryż można jeszcze wysyłać! Chleba nie trzeba! Potrzebne są również mały kubek i aluminiowa miseczka. Mąki kukurydzianej troszkę od Hani jeśli można. Piszę o tej przesyłce, ale nie wiem, czy będziecie mogli mi coś wysłać. Chciałbym bardzo, aby moje dzieci coś upiekły i wysyłały. Czy chodzą do szkoły i ponownie pytam, czy wszyscy jesteście zdrowi? Niech każdy do mnie coś w liście napisze i napiszcie do mnie wyraźnie, co wysyłacie! Pieniądze ... tylko przekazem! Pamiętajcie o tym, że muszę i z innymi się podzielić, dlatego trzeba wysyłać wszystkiego więcej! Jeden grubszy koc (odzież) i ręcznik przydałby mi się! U adwokata Friedmana odbierzcie 100 rubli! Już rok jak pożyczył. Napiszcie do mnie o wszystkich znajomych, a przede wszystkim o sobie. Czekam na wiadomość od Was! SZYBKO!!! Myślę o Was bez przerwy i czekam, kiedy się spotkamy! Czy dzieci wyrosły? Bardzo Was proszę, co możecie przyślijcie - podajcie adres Kazia. Mocno Was całuję po rękach i życzę Wam wszelkiego dobra z okazji Nowego Roku. Wasz Saniu [Sianio, Sianek, Sianiu - Issak Antoni Donigiewicz].

${ }_{28}$ Tato - Teodor Donigiewicz, ojciec autora listów, dzierżawca ziemski.

29 Anka, Duszka, Duszyczka - Anna z Ohanowiczów Donigiewiczowa (26 października 1894 - 2 listopada 1948, Bytom), żona autora listów, nauczycielka.

${ }^{30}$ Kolowie - Mikołaj Łazarowicz i jego żona Anna (córka Katarzyny z Nikosiewiczów i Bogdana Agopsowiczów); mieszkali po sąsiedzku z Donigiewiczami przy ul. Zielonej 6 w Kutach, po wojnie osiedlili się w Bielsku-Białej.

31 Tolkowie - Antoni Donigiewicz, brat autora listów, kapitan WP w Stanisławowie, i jego żona Zofia. Antoni z synem Andrzejem, również wojskowym, doszedł z frontem aż pod Berlin, zmarł w 1946 roku. 
O sobie prócz tego żem jako tako zdrów - nie mam co pisać.

Najdrożsi! W poprzednim liście pisałem Wam żem prosił Kaja z Jasienowa by Wam przywiózł zboża i kartofli, nie wiem czy Wam dał! Teraz piszę znowu i do Niego. Was poprzednio prosiłem o pakunki jeśli bez uszczerbku dla siebie to proszę $1 \mathrm{~kg}$ cukru, $8 \mathrm{~kg}$ mąki kukur[ydzianej] (może z Kut). (aha! paczki mogą być po $8 \mathrm{~kg}$ ) $4 \mathrm{~kg}$ czosnyku i z $3 \mathrm{~kg}$ cebuli - koc z jadalnego - 1 ręcznik, kawał słoniny bo to mi bardzo brak, mięsa od maja nie widziałem!!! Garnuszek alum[iniowy] na herbatę (wodę got[owaną]) i ryneczkę alum[iniową] na kuleszę i topienie słoniny - troszkę bryndzy - ściereczkę, z biurka u Zańka tytoń, jeśli nie ma, to machorki lub innego, papierków dużo i listowego pap[ieru]!

Co do sucharów to bardzo proszę o jakieś placki z makiem, rogalki, bułeczki ale to wszystko musi być słodkawe bo chleba nie wolno - nie trzeba.

Uważaj Anko, że muszę i innym coś dać. Pakunki posyłaj co 2 gi lub 3 ci dzień.

Mocno Was wszystkich ściskam i całuję. Sianio

[pionowy dopisek:] 20 do 30 rubli zapakuj w bułkę i lepiej ją wypiecz. Na końcu w liście daj znaki xxx o pieniądzach nie pisz. Rysieńko ${ }^{32}$ i Myszko ${ }^{33}$ coś napiszcie do Tatusia i upieczcie dobrego.

\section{3.}

Najdrozsi Moji!

Iwdel 27/2. [19]41

Po kilkudniowej przerwie piszę znowu do Was! Chciałbym z Wami co dziennie rozmawiać choćby tą drogą - ale czas mi nie pozwala. Ciekaw jestem bardzo czyście otrzymali moje poprzednie listy i czy możliwem jest wysyłka tego o co prosiłem? Dotychczas od nikogo nie mam żadnej wiadomości - niespokojny jestem bardzo o Was wszystkich - czy jesteście zdrowi - jak żyjecie - czy Dziadzio $^{34}$ się trzyma - Ty Anko i Marylko jak się czujecie - jak sobie radzicie, a co moja Rysieńka i Myszuchna robią - czy chodzą do szkoły - czy zmieniły się i urosły? Bardzo Was proszę - niech każdy z osobna coś do mnie napisze - będzie dowodem o jego życiu! Znowu zapytam o Kazia adres - co z Romkami, Tolkami, Ciubą - Wasiem, Kasunią - Nusią - babcią Hanią ${ }^{35}$ - stryjenką Pietrunią - Krzy-

32 Rysieńka - Teresa z Donigiewiczów Płytyczowa (7 maja 1927, Kuty - 17 października 2014, Bytom), córka autora listów, po wojnie prawnik i działaczka społeczna na Śląsku.

33 Myszka, Myszuchna - Maria Donigiewiczówna (7 maja 1931, Kuty - 10 stycznia 1993), córka autora listów, po wojnie doktor medycyny na Śląsku.

${ }^{34}$ Dziadzio - Jan Ohanowicz (18 kwietnia 1864, Bołszowce - 19 marca 1954, Bytom), teść autora listów, sekretarz wiejski w Tiudiowie; w latach dwudziestych XX wieku zarządca dóbr Tarnowskich w Tarnobrzegu i folwarku Nora-Grobla koło Jarosławia.

35 Babcia Hania - prawdopodobnie chodzi o Annę z Bohosiewiczów Donigiewiczową, żonę Antoniego, babkę autora listów. 
siami, i w ogóle innymi krewnymi i znajomymi? My mieszkamy dość porządnie. Mamy radjo w baraku i słuchamy komunikatów. Pracujemy i tak dnie schodzą. Czekam bardzo od Was wiadomości i choćby co dnia wysyłajcie do mnie kartkę! Prócz poprzedniej prośby mojej o wysyłkę miałbym dalszą - potrzebuję 2 koszule dzienne, 3 koszule wykładane, z 2 p[ary] kalesonów długich i z 3 krótkich, kilka chustek, ręcznik, ścierka - mydła kawałek, szczoteczka do zębów, skarpetki cienkie i zimowe po 2 pary i ubranie migdałowe. Możnaby to wszystko w cienki kocyk czerwony zawinąć i obszyć. Poprzednio prosiłem o garnuszek, szynkę i inne rzeczy - sam nie wiem czy coś będę mógł dostać od Was - okropnie męczy mnie niepewność i brak dla Was środków do życia. Napiszcie w listach o czemś okropnym - „ogródkami”.

Od Kajcia z Jasienowa nie mam jeszcze odpowiedzi - nie wiem czy był u Was?

W każdym razie nic nie oszczędzajcie, żyjcie i radźcie sobie jakimikolwiek środkami, by wyżyć! Futro sprzedajcie, obrusy, naczynie, radjo, lampę i t. d. -

Chciałbym dalej rozmawiać - lecz papier i czas wstrzymują. - Mocno Was wszystkich ściskam - po łapach całuję - a dzieci bardzo - bardzo mocno. Napiszcie zaraz i często. Adres: Село Ивдель, Сьвердловская Область,

Ящик почтовий 232/09, Доничевич [!] Иссак Теодорович. Sianio

\section{4.}

Najdrozsi Moji!

Iwdel 21/3. [19]41

Przeszło miesiąc nie pisałem do Was, najpierw wyczekiwałem wiadomości od Was - później przechorowałem się z 3 tygodnie - ale jest mi już lepiej. Dzisiejszy dzień - pierwszy dzień wiosny nastraja mię do listu; - chociaż u nas jeszcze zima mocna i nawet mrozy panują, cieszę się, że wkrótce zabłyśnie słońce i nam przygrzeje! Pierwszą wiadomością była depesza Kajcia, następnie jego list polecony ze Stanisławowa, poczem list Marylki a na końcu kartka Andy [?] z 24/2. którą dostałem dopiero 16/3. - Wiadomościami o Was - możecie sobie wyobrazić jak się ucieszyłem! Dopiski wszystkie - względnie listy „dziecinne” czytałem po kilka razy - a co dnia listy przerzucam i zdaje mi się, że z Wami rozmawiam. Prócz tych wiadomości do dziś nie mam nic, ani pakunków, ani pieniędzy. Jeszcze raz proszę, pieniędzy mnie przekazem nie posyłajcie - i te o ile przyjdą tak od Ciebie jak i od Kajcia każę wysłać Tobie - a Ty rób tak jak uważasz! Napiszcie mnie już raz, które listy odemnie dostaliście podług dat i dlaczego tak mało do mnie piszecie? Wiecie dobrze, że ja ani kopert ani listu nie mam i tu za żadną cenę nie dostanie [się]. Byłbym wcześniej napisał do Was, ale czekałem na przesyłkę i czekam nadal niecierpliwie. Możecie posyłać jak chcecie i kiedy chcecie, jak wyszlecie to wszystko o co prosiłem, to następną po Świętach, bo chcę bardzo podzielić się z Wami czemś Świątecznem! A może nie dostaliście 
moich listów, o ile pamiętam wysłałem do Marylki 3 albo 4 listy! O sobie nie mam co pisać... żyję i tyle! Co Bóg da - to będzie - nadzieja i myśl o Was jest dla mnie wszystkiem! Proszę Was piszcie do mnie choćby co dnia, w listach niech każdy coś napisze, a dzieci najwięcej. Specjalnie tak proszę, by były grzeczne, by coś nie zbroiły, mogą w nieszczęście wpaść. Drobnostka - zabrany ołówek 81 [etniej] koleżance - 1 rok! - Proszę więc Was dzieci bardzo, zachowujcie się bardzo przyzwoicie!!! Do Tatusia piszcie często i proście Waszą Patronkę byśmy się szybko zobaczyli! Za otrzymane od Was wszystkich wiadomości serd[ecznie] dziękuję. Cieszę się ogromnie, że trzymacie się zdrowo i dajecie sobie radę! Anko - powiedz przy sposobności Kaziowi, by lokalu swego nie zmieniał - niech tam mieszka gdzie jest - bo lepszego nigdzie nie znajdzie!!! Do Tolków jak będę miał list napiszę. Teraz wysyłam ostatni mój papier i czekam na przesyłkę papierów, o które też prosiłem!!! W listach wspominajcie o wszystkich krewnych i znajomych - myślę o wszystkich i wspominam! Wprawdzie Marylka obiecała często pisać - ale już 10 dni minęło - list jej dostałem 11/3 - a nic nie mam. Może teraz się poprawicie? Co?

Brak thuszczu i cukru spowodował u mnie początki s[z]korbutu - ale ratują tu lekarze wszystkich starannie i choroba ustępuje! Serce trochę mnie dokucza zresztą wszystko nic - nie mogę mam co o tem pisać! I w ogóle o sobie nic więcej nie piszę. Listy odemnie będą znakiem życia - reszta potem!

Kończąc - wszystkich Was mocno ściskam i całuję Dziadziowi - Cioci Pietruni - Kasuni i innym rączki całuję. Serd[ecznie] Pozdrawiam. Sianio.

[pionowy dopisek:] Czekam bardzo lata-zbierają się chmury-będzie gorące lato!

\section{5.}

Kochana Rysieńko i Myszko!

Iwdel 21/3. [19]41.

Pisząc list do Mamusi i do Was piszę króciutki liścik, bo nie mam więcej papieru. Cieszę się bardzo, że się dobrze uczycie, i że macie polską szkołę. Uważajcie na siebie byście się nie przeziębiły, bo teraz pod wiosnę nie trudno! Zachowujcie się grzecznie, myślcie dużo o Tatusiu, który tylko o Was myśli, i chciałby bardzo już z Wami być. Nie martwcie się i to nastąpi tylko proście Wasze Patronki, by przyśpieszyły powrót Tatusia!

Kochane Moje pieszczotki! Napiszcie mnie gdzie chodzicie się bawić i czy żyjecie z jakiemi koleżankami? Aha! Zapomniałem Wam napisać byście w domu były grzeczne i [nie] robiły hałasu, bo Dziadzia denerwujecie! Napiszcie zaraz do Tatusia, bo bardzo czekam od Was wszystkich wiadomości!

Mocno Was całuję i ściskam. Tatuś 
6.

Najdroższa Duszyczko!

Iwdel 21/3. [19]41.

Specjalny dopisek do Ciebie! Możeby dało się zrobić prośbę o mnie i Kazia do Stalina $^{36}$. O mnie imieniem dzieci! W Stanisławowie ma być adwokat sowiecki, który się na tem zna - do tego potrzeba opinji z Gminy! Za Kazia - tato! Zresztą nie wiem jaka tam sytuacja z nim. Możeby to zrobił dr Steigman z Kut. Słyszę, że prośby odnoszą skutki w niektórych wypadkach. Zastanów się jednak dobrze, czy opłaci się to zrobić..? Aha! Czy odebrałaś od adwokata Friedmanna 100r.

Duszyczko! Listy [pisz] do mnie często. Wysyłaj choćby co 2gi dzień jakąś wiadomość - tem tylko żyję, bo zresztą nędza! Mocno ściskam i całuję. Sianek

\section{7.}

Iwdel 27/3. [19]41.

Najdrozsi!

Dnia 21/3 wysłałem list - nie wiem czy dostaliście - czy nie? Obecnie wysyłam drugi i bardzo Was proszę wyraźnie zaznaczajcie datę listów otrzymanych! Przykro mnie jest bardzo, ale muszę jednak zarzucić Wam, że chyba o mnie zapomnieliście - gdyż od przeszło 11 dni nic od Was nie mam, ani kartki - (o przesyłkach do dziś nie ma mowy), czy tak trudno wysłać choćby słów kilka w kartce co drugi dzień!!! Nie mogę tego pojąć dlaczego nie otrzymałem dotychczas przesyłki ani od Kajcia ani od Was - gdy tymczasem inni dostają wszystko, a ja zaglądam jak zajadają i słoninę - mięso - ciastka - cukier i inne domowe bułeczki lub placki. Prosiłem o czosnyk i cebulę, bieliznę - koc gruby i ubranie letnie, skarpetki zimowe i letnie, chusteczki i ręczniki (może te z Kosowa), jakąś ryneczkę i garnuszek aluminjowy. Pakunki można przesyłać 3 miesięcznie - po $8 \mathrm{k}$ [i]1[o]gr[amów]. Zresztą to zależy od tamtejszej poczty. Papier listowy, koperty, papierki do tytuniu papierosów machorki. Tytuniu jak najwięcej. Chciałbym i trochę mąki kukur[ydzianej] ale nie wiem jak z tym jesteście w zapasie. O cukier i tłuszcz (słonina) przede wszystkim proszę. Wyliczyłem jeszcze raz to samo, co w poprzednim liście pisałem - nie wiem czy tamten dostaliście? Zaznaczyć muszę, żebyście w przyszłości żadnych pieniędzy telegraficznie nie posyłali - tylko tak jak już raz pisałem! Listów do paczek nie dawajcie - tylko pocztą wysyłać! Te pieniądze, które ty mnie Anko posłałaś telegr[aficznie] najprawdopodobniej wszystkie zwrócę, albo zatrzymam z 20 - 30 rubli - inne pieniądze mogę odbierać (drobne kwoty) w „kaczuszkach”.

${ }^{36}$ Chodzi o petycję w sprawie ułaskawienia, skierowaną do Józefa Stalina, wtedy sekretarza generalnego Wszechzwiązkowej Komunistycznej Partii (bolszewików), faktycznie dyktatora Związku Sowieckiego. 
Od Kajcia też jeszcze niczego nie dostałem, pieniądze Tobie wyszlę. Ciekaw jestem czy już dostałaś z Melitopola ${ }^{37}$ mój pierścień i 6 koronek zębnych, które kazałem Ci odesłać!? O Kaziu pisałem, by starał się dotychczasowe lokum zatrzymać, bo lepszego nie znajdzie! Co Wy porabiacie? Jak dopisuje zdrowie? Czy macie już wiosnę - u nas jeszcze zima! Co porabiają wszyscy krewni i znajomi? O ile wyczuwam, że zbliżają się Święta, kiedy są dokładnie nie wiemy, liczymy na 12/4, w każdym razie składam Wam Wszystkim najserd. życzenia, zdrowia pomyślności, niech Was Pan Bóg ma w swojej opiece i utrzymuje przy życiu jak najdłużej!!! Ja o sobie nie mam co pisać - praca - jest mi ciężko, bo nic nie mam - ani grosza, ani przesyłek! Zdrowie, serce - nieszczególnie.

Anko, Ty spieniężaj co można i dawajcie sobie radę - aha, dlaczego tylko 1/2 świnki zabiliście, z czem będziecie cały rok? Zaraz mnie odpiszcie - i piszcie często!!!!!!

Kończąc mocno Was wszystkich ściskam i całuję - Dziadziowi rączki. Sianek

8.

Iwdel 27/3. [19]41.

Kochane i Drogie Moje Dzieci! Dlaczego Wy nic do Tatusia nie piszecie a czy upiekłyście Tatusiowi coś dobrego, tak, jak Was prosiłem?! Czyście zdrowe? Piszcie często! Mocno Was całuję. Wasz Tatuś.

9.

Iwdel 5/4. [19]41.

Najdrozsi!

Wczoraj odebrałem paczkę Waszą z 4/3 - zupełnie w porządku - chociaż była spóźniona. List Twój Anko z 3/3 i Myszki jakie były razem, wyjątkowo odebrałem razem z paczką. Listów więcej w paczkach nie posyłajcie! Listy z paczki z 10/3 nie oddano mnie. O tem już w poprzednim liście pisałem i opisałem o wszystkiem jak trzeba postępować - więc też do tego trzeba się dostosować! Ostatnio wysłałem do domu 3 listy (21/3 - 27/3 - 3/4) obecnie czwarty z rzędu proszę mnie dokładnie napisać, które otrzymaliście? I kiedy? Jak już doniosłem Kajcio nie dołączył wszystkich drobiazgów, które mu wręczyłaś - pewnie wyszle to inną paczką. Co do czwartej paczki (dwie od Kajcia - dwie Wasze) nie robiono mi żadnej trudności i jak widzę można odbierać ile poszlą! Nie piszę to dlatego byście często wysyłali. Sądzę, że raz lub 2 razy miesięcznie wystarczy - a chodzi głównie o tytoń, papier, czosnyk, cebula, tłuszcz i bułki, (powidła lub z konfiturą, miesznina). Nie wiem, czy doszedłby dobrze kołacz i makownik? Zresztą, co można zrobić bez dużego wydatku!!!

${ }^{37}$ Melitopol - miasto w południowo-wschodniej części Ukrainy, w obwodzie zaporoskim. 
Aha! Wciąż mam na myśli - dlaczego tylko połowę świnki zużyliście dla siebie - czy przez gotówkę - przecież mało Wam będzie thuszczu i wędlin - nie mając salcesonów! - A czy inna świnka kręci się już koło domu? Trzeba koniecznie o tem pomyśleć, bo cóż będziecie przegryzać? Czy ja mam tu i o tem myśleć - dość, że wciąż nasuwa mnie się myśl, skąd Wy sobie radę dajecie i tak mocno zapewniacie, że niczego Wam nie brak! Chciałbym bardzo by tak było, dlatego też Anko jeszcze raz piszę - sprzedawaj co można i żyjcie, by Was siły nie opuściły!

Czy Kajo był już u Was? Wracając jeszcze do listów i paczek - jeszcze raz za wszystko serd[ecznie] dziękuję i mocno Was wszystkich ściskam i całuję! Dzieciom osobno odpisuję!

Anko! Mam specjalną prośbę! Chodzi mnie o znajomych. Wyszlij kartkę pod adresem: Stankiewicz Ludwik, Legjonowo koło Warsz[awy] ${ }^{38}$ - Grudziński Wacław $^{39}$ zdrów, był z moim mężem dłuższy czas razem.......! Przesyła pozdr[owienia] z Rosji. Podpis. Drugą kartkę wyszlij pod adresem: Gabrjela Gowatko, Warsz[awa] [ul.] Hoża No $58 \mathrm{~m}$. 22. Jestem zdrów - jako tako żyję - przebywam w Rosji. „Bronisław”. Jeśli możesz podaj im swoje adresy, a jak coś napiszą donieś mi!

Proszę Was bardzo piszcie do mnie często i dużo o sobie i w ogóle o wszystkich! Jak się czuje Kazio? Co porabiają domatorki, przybrane babcie, dzieci? Posyłam serd[eczne] pozdr[owienia] i ucał[owania] rączek dla wszystkich krewnych i znajomych! Kończąc wszystkich Was mocno ściskam i całuję - Dziadziowi rączki. Sianio

\section{0.}

Kochane Moje Dzieciaki!

Z ogromną radością czytam Wasze listy i cieszę się, że dużo i o wszystkiem do mnie piszecie! Przysmaki, któreście upiekły bardzo mnie smakowały! Za orzeszki, cukierki i ciastka mocno Was całuję. Dziwnem mnie tylko wydaje się gdzie znikł „piernik” o którym Myszka wspomina? Co Muciu na to powiesz? Może się nie udał? A co dzieciaki na święta pieczecie? Może ładną pisankę mnie poszlecie - a czy przekładaniec będzie na stole? Pamiętajcie, byście i za mnie zjadły jajeczko święcone!!!

${ }^{38}$ Ludwik Stankiewicz (1865-1953) i jego żona Maria Młodziejewska Stankiewiczowa (1875-1957) byli właścicielami zbudowanej przez siebie w 1926 roku drewnianej willi przy ul. Warszawskiej $72 \mathrm{w}$ Legionowie.

39 Wacław Grudziński - mąż Natalii ze Stankiewiczów, żołnierz WP; symboliczne upamiętnienie jego losów, tablica z napisem: „Jeniec wojenny bestialsko zamordowany przez sowieckich oprawców" znajduje się na grobowcu rodziny Stankiewiczów na cmentarzu Bródnowskim w Warszawie. Prawdopodobnie chodzi tu o Wacława Grudzińskiego (ur. 1892), syna Erazma, aresztowanego w województwie stanisławowskim w 1940 roku. 
Piszcie do mnie często! Mocno Was ściskam i całuję. Wasz Tatuś

[pionowe dopiski:] Czy otrzymałaś 6 koronek zębnych i pierścionek? Dla dzieci załączam znowu 2 znaczki.

11.

Najdrozsi!

Iwdel 12/4. [19]41.

List Anki z 24/3 pisany w Stanisł[awowie] otrzymałem 2/4 i z miejsca zapytuję jak sprawę tam załatwiłaś? Czy zastałaś Kazia? Czy Ty się z nim widujesz i rozmawiasz? Jak on się czuje? Za wiadomości serd[ecznie] dziękuję! Nie wyobrażacie sobie nawet jak czekam listów od Was - a jeśli go dostanę - czytam po 10 razy - względnie uczę się na pamięć! Dnia 10/4 otrzymałem depeszę - mojem zdaniem był to zbędny wydatek - ale stało się! W każdym moim liście potwierdzam odbiór listów od Was, tak, że można przekonać się czy wszystkie otrzymuję! Ja prowadzę zapiski listów przezemnie wysyłanych i zaraz po otrzymaniu odpowiedzi od Was stwierdzam, który doszedł, a który zaginął. Jak przekonałem się nie otrzymaliście moich listów z 12/12 [1940] - 17/2 - 22/2 - poczem z 21/3 - 27/3 - 3/4 - 5/4 [1941] - no, te jednak nie mogliście jeszcze dostać. Potwierdzenia Wasze odnoszą się do moich listów z 7/2 - 10/2 i 27/2. W poprzednich listach napisałem już o odbiorze paczek a to od Kaja dwóch z 10/3 i Waszych z 4 i 10/3. Awizowanej paczki z 20/3 (listem ze Stanisławowa) jeszcze nie otrzymałem - spodziewam się, że lada dzień nadejdzie. Ponieważ w poprzednich listach napisałem co Kajo posłał, przeto teraz powtarzał nie będę - zaznaczę, że wszystkie paczki zupełnie w porządku przyszły i po przeglądnięciu ich zawartości - mnie wydano! Abym nie zapomniał, chcę powiedzieć byście drogich papierosów nie kupowali - posyłajcie mnie tytoń jakiś tańszy - dużo machorki, i z 20 paczek może być (w paczkach po 35 gr.) a trochę jakiegoś lepszego! Czy mojego tytoniu - tego z biurka już nie ma więcej? Jeśli jest, wszystkie paczki mnie przyszlijcie!!! Bibułek dobrych jak najwięcej.

Z listu ostatniego wiem, co w paczce z 20/3 znajduje się! Najbardziej cieszę się z listów moich pieszczotek. Na to też bardzo czekam. Listy starszych proszę wysyłać tylko pocztą! Nie mówię już nic o pierniku, który Myszka spiekła, a który musi być bardzo smaczny. Z góry też dziękuję za bryndzę. Będę miał w gębach trochę huculszczyzny, za inne ... kawałki też dziękuję - chociaż jeszcze nie otrzymałem! Jak zauważycie z daty jest to sobota W[ielka]. Dziś jestem wolny od pracy - jutro też - ręka mi spuchła i chodzić do roboty nie mogę! Jutro gotuję wielką kuleszę - to zastąpi nam babkę wielk[anocną]. A może i jajko dostanę więc tak spędzę święta! Myślą będę wciąż z Wami. Od godz. 2 w południe (Wasza 10ta rano - bo między mną a Wami jest 4 godz. później) jestem u Was - zasiadam do stołu i wspólnie, jak zwykle, dzielimy się tradycyjnym jajeczkiem - składając 
sobie życzenia! Życzenia te zbiegną się w tym roku w jednym kierunku!!!!!! Ciekaw jestem bardzo co po świętach Mucia mnie poszle? O ładną pisaneczkę bardzo proszę! Natomiast przekładańca, makownika - pasek i sernika i innych „bakaliji” mamusinej roboty chcę.......

Czy nie mogłabyś Anko dostać w Kutach suszu? Może Tomiuk da dla mnie ze $10 \mathrm{~kg}$, z tego byś i mnie trochę posłała! Aha! Twoją setkę pobrano i wypłacono mnie aż 5 rubli, jak napisałem - zwrócę pieniądze, a Ty już wiesz, co masz z niemi zrobić! Koniecznie Ciebie proszę oddaj Halusi ${ }^{40}$, córce Kajcia Agops[owicza $]^{41}$. 5 rubli, będąc $\mathrm{z}$ nim razem pożyczyłem, a gdy nas rozdzielono i adresu jego nie znam - nie mogę mu oddać - więc niech ona jemu odeszle odemnie! Czy nie słyszeliście coś o ks. Bodziu ${ }^{42}$ ? Proszę odpisujcie mnie na wszystkie moje pytania!!! Nie dając długo czekać na odpowiedzi!!! Czy str[yjenka] Pietrunia będzie u Was w czasie Świąt? Napiszcie jak spędzacie w ogóle dnie - co robicie - jak dopisuje zdrowie Wam, krewnym i znajomym? Wszystkich odemnie pozdrawiajcie! Co robią Hord. ${ }^{43}$ Ohol. Gard. ${ }^{44}$ Sorger $^{45}$ - Bodzio Nors ${ }^{46}$. I w ogóle wszyscy znajomi!? Moją chrześniaczkę Wisię ${ }^{47}$ mocno ucałuj! Czy Krzysiowie mieszkają u siebie? Co z Anielką i Tolkiem Migo ${ }^{48}$ ? Słyszałem, że w domu!? Czy babcia Tosia trzyma się mocno? Czy Tadziowie i Romkowie pisali? Może teraz listy nie przechodzą? Czy dało się zawiadomić rodziny tych, o których pisałem. Rozmawiałem z Wami długo! Zapytam teraz Rysieńkę i Myszkę jak one Święta spędziły - czy bawią się z koleżankami - czy chodzą czasem do cioci Hani - czy

${ }^{40}$ Halusia - Halina z Agopsowiczów Kurowa, urodzona 12 kwietnia 1924 roku, obecnie mieszka we Wrocławiu.

${ }^{41}$ Kajcio Agops. - Kajetan Agopsowicz, mieszkaniec Kut, ożeniony z Emilią z Donabidowiczów, ojciec ks. Bogdana, Marii Chrzanowskiej i Haliny Kurowej; po zamordowaniu syna został aresztowany przez NKWD i był więziony na Kołymie, zaś jego żonę osadzono w Kazachstanie.

${ }^{42}$ Ks. Bodziu - Bogdan Agopsowicz (1908, Kuty - 1940, Kuty); święcenia kapłańskie w obrządku ormiańskokatolickim przyjął w 1936 roku; zastrzelony przez sowieckich okupantów w 1940 roku podczas przekraczania granicy na Czeremoszu, po czym nastąpiła fala aresztowań i wywózek Polaków i Ormian z Pokucia.

${ }^{43}$ Hord. - prawdopodobnie chodzi o rodzinę Hordyńskich mieszkającą w Kutach przy ul. Zielonej 1: Dominika Juliana (1886-1943), dyrektora Szkoły Żeńskiej, aresztowanego przez okupantów niemieckich i zamordowanego w niemieckim obozie koncentracyjnym na Majdanku, jego żonę, nauczycielkę, i synów - Jerzego (1918-1998), poetę, żołnierza Armii Krajowej, aresztowanego po powtórnym zajęciu Lwowa przez wojska sowieckie w 1944 roku i zesłanego do łagru, oraz Józefa (zm. 1941).

${ }^{44}$ Gard. - może chodzi o adwokata kuckiego Mariana Gardeckiego.

45 Samuel Sorger - mieszkaniec Kut wyznania mojżeszowego.

${ }^{46}$ Bodzio Nors - Bogdan Norsesowicz, radca sądowy, burmistrz miasta Kuty (19291934), prezes miejscowego oddziału Archidiecezjalnego Związku Ormian.

${ }^{47}$ Wisia - Jadwiga Ciesielska, córka Katarzyny Janowicz, przysposobiona przez Jana i Marię Ohanowiczów, teściów autora listów; po wojnie osiedliła się w Łodzi.

${ }^{48}$ Migo - prawdopodobnie chodzi o kucką rodzinę Migockich. 
często chodzą do kościółka i proszą swoje Patronki o zdrowie dla wszystkich i powrót Tatusia?!? Piszcie dzieciaki do mnie często! A możeby tak Dziadzio i stach. [?] Marylka też coś napisali? Kończąc wszystkich Was bardzo mocno ściskam i całuję - Dziadziowi rączki - Sianek

Christos harjaw! ${ }^{49}$

[pionowy dopisek:] Czy otrzymałaś 6 koronek zębnych i pierścionek? Dla dzieci załączam znowu 2 znaczki.

12.

Najdrozsi!

Iwdel 16/4. [19]41

Dnia 12/4 wysłałem listy do Was - Dzisiaj piszę ten, bo jednak trochę denerwuję się brakiem wiadomości od Was! Bądź co bądź mija już 14 dni od ostatniego listu Anki (Stanisł[awów] 24/3.) a depeszy 6 dni! Tłumaczę sobie to krzątaniną domową - lecz zawsze ktoś może kartkę wysłać! Czy dzieci też nie mogą napisać? by nie robić tak długiej przerwy? Do dnia dzisiejszego nie nadeszła jeszcze paczka z 20/3. ale spodziewam się ją lada dzień odebrać! Czy to prawda, że nadanie jednej paczki do nas kosztuje aż 40 rubli?

Poprzednio pisałem już, byście nie kupowali drogich papierosów i tytoniu za te pieniądze lepiej nakupić dużo paczek machorki lub papierosów po 35 kop[iejek] (25 sztuk). Na myśl, że tak drogo przesyłka kosztuje - odechciewa się tych paczek - skąd na to wszystko się bierze - nie wiem?! Ciekaw jestem czy Kajo był u Was przed Świętami i co przywiózł?

Do mnie, prócz tych paczek, o których już Wam pisałem, nic więcej nie pisał - ani posyłał!

Dziś już po Świętach! Jak spędziliście takowe, kto był u Was - a gdzie Wy bywacie? Czy dzieci miały wolne i jak długo? Ja jeszcze siedzę zwolniony - lecz za 2-3 dni już pójdę do roboty.

Równocześnie z tym listem wysyłam list i do stryjanki! Wypytuję o różne kuckie wiadomości, bo ciekaw jestem o takowe!

Co porabiacie wieczorami? Czy Dziadzio stawia pasjansy? Czy zdrowie Wam wszystkim dopisuje? Co z Kaziem? Czy piszą co Romkowie i Tadziowie? Proszę Was bardzo piszcie często do mnie - bo tym żyję!!!

Ja się trzymam - po za tem nic nowego! Czekam lata i gorąca, a z nim „,moskitów" które tu są i dokuczają! Od kilku dni przygrzewa słońce i śnieg gwałtow-

49 Christos harjaw! - w dialekcie Ormian kuckich pozdrowienie wielkanocne: Chrystus zmartwychwstał (zniekształcenie od: ephuunnup hupnıpjnıl wnuц - Kristosy harutiun arraw). 
nie taje! Z pod śniegu pokazały się leśne kwiatki - przesyłam je dzieciom - jak również załączam znowu dwa znaczki dla nich! Poprzednio też dołączałem, czy dostały nie wiem? Kwiatki niech schowają, będą miały pamiątkę z Uralu!!!

Znowu zapytuję - czy otrzymałaś zębne koronki i pierścionek? Napisz mnie o tem zaraz, bo muszę sprawę pourgować! ${ }^{50}$ Kiedyśto wyrwałem tu dwa zęby może sobie przypominasz - przednie z białego metalu, robił Knoller! $!^{51}$ Jestem już bezzębnym dziadkiem! Aha! Tyle razy chciałem się zapytać, jak ograniczyliście się z mieszkaniem? Co płacicie? Czy Ryśka korzysta z pianina? Sądzę, że mając takowe w domu, szkoda, by nie uczyła się! A może Myszka już brzdąka? Czy Myszka ma duże włosy? Czy dzieci urosły - no i zmądrzały? Czy razem wychodzą z domu do szkoły?

Kończę już - bo też i dość nabazgrałem, a teraz nie napiszę, dopóki coś od Was nie nadejdzie!

Rączki całuję Dziadziowi - Was wszystkich mocno ściskam i całuję

Sianek

[pionowy dopisek:] Anko! Staraj się ściągnąć od Dziunia 2 worki pszenicy!

13.

Najdrozsi!

Iwdel 1/5. [19] 41

Dziś $1 / 5$ - dzień wolny od pracy - więc też z rana zabieram się do napisania listu! - Ostatnio - wypadła dłuższa przerwa w pisaniu - albowiem od 16/4 nie pisałem dla braku czasu! Do dziś zapewne otrzymaliście moje listy z 3/4 - 5/4 - 12/4 i $16 / 4$. -

Ja natomiast - otrzymałem od Was paczkę z 20/3. - 30/3 i 3/4 razem z listami - (listów jednak więcej w paczkach nie posyłajcie)! Oprócz tego odebrałem kartkę Myszki, i list polecony Anki z 7/4. Za wszystko - wszystkich mocno ściskam i całuję! Oprócz tego muszę osobno wyrazić podziękowanie za świetną kiełbasę, bardzo smaczną - słoninkę - sucharki, a przedewszystkiem, za cukierki, pierniczek - i inne przysmaki - oraz za kwiatuszki, które moja Myszuchna uzbierała i ususzyła! Bryndza - druga, jest bardzo dobra! W ogóle wszystko doszło w porządku i w całości odebrałem! Naprawdę - pomijam, że wysyłkami tymi dokarmiam się sam - lecz i inni Wam szlą serd[eczne] podziękowania, gdyż także po trochę korzystają i tak żyjemy jak w szałasie cygańskim razem obozując i jedząc! Kilka razy gotowałem w wiadrze w lesie dużą kuleszę i zajadaliśmy samą. Bułeczka, którą ostatnio otrzymałem uchodzi tu za najlepszy tort. -Wiem,

${ }^{50}$ Urgować - przyspieszać, przynaglać, nalegać (za niem. urgieren, z łac. urgere).

51 Zygmunt Knoller (ur. 1899) - dentysta kucki. 
że teraz coś dostanę „Świątecznego” bo mnie to bardzo „pachnieje” pod nosem! Ucieszyłem się bardzo tem, że Kajcio był u Was i coś przywiózł. Kiedy wyszle resztę z tego coś mu Anko dała, bo do dzisiaj nie otrzymałem!

W sprawie moich „Koronek”, robię dzisiaj ponowne pismo, by je Tobie wysłali - szkoda przecież tak Koronek jak i pierścionka. Oprócz tego wyjąłem dwa zęby przednie (z białego metalu) względnie jeden zjadłem, a drugi też gdzieś się zadział. Jestem teraz już naprawdę bezzębną babcią.

W tem miejscu - zapodam, że otrzymałem 5 lat - termin 12/5 1945. Prośbę należy skierować do Kalinina ${ }^{52}$ i Stalina, ale tylko imieniem dzieci!!! Dlaczego wysłałaś prośbę do Stanisławowa?

[strona 2]

Więcej nic nie piszę - ze zrozumiałych powodów! Was natomiast bardzo proszę piszcie o sobie dużo wogóle o wszystkich krewnych i znajomych - jak również napiszcie coś o cioci „Gerze" ${ }^{53}$ co ta wyrabia i kiedy skończy się jej szastanie po cudzych domach?! O niej już od 10 dni nic nie wiem, ani o cioci Ańdzi ${ }^{54}$ Turczynce ${ }^{55}$ i Soni ${ }^{56}$ - bo „Głos” ${ }^{\text {57 }}$ nie dochodzi - po prostu zabrano i nie mamy żadnych o nich informacji! - Czy wszyscy jesteście zdrowi - jak trzyma się Dziadzio? Czy był ktoś u Was w czasie Świąt? Aha! Anko! Czy dałaś Halusi 5 rubli, które pożyczyłem od Kajcia Agops[owicza] a później nas rozdzielono. Od tygodnia zabrano część, między nimi znalazł się i Jaśko Baumgartner ${ }^{58}$, dokąd - nie wiem, zdaje mnie się że i ja wyfrunę stąd w inne łagry! Na razie adres ten sam!

Z ubrania mojego, w którem wyjechałem jeszcze pozostała mnie kamizelka, ze spodni już zupełnie wyłażę a marynarki nie mam! Mam jakąś fufajkę i nic więcej! Futerka na razie nie potrzebuję. Palto moje bardzo zniszczone [dwa ostatnie słowa w pionowym dopisku].

${ }^{52}$ Michaił Kalinin (1876-1946) - rosyjski działacz komunistyczny, od 1919 roku przewodniczący Ogólnorosyjskiego Centralnego Komitetu Wykonawczego Rad Rosyjskiej Federacji Socjalistycznych Republik Sowieckich, czyli formalnie głowa państwa; po utworzeniu Związku Socjalistycznych Republik Sowieckich połączył tę funkcję ze stanowiskiem przewodniczącego jego Centralnego Komitetu Wykonawczego, czyli głowy państwa związkowego, od roku 1938 roku - przewodniczący Prezydium Rady Najwyższej ZSRS.

53 Ciocia Gera - autor listu ma zapewne na myśli Niemcy (Germanię).

${ }^{54}$ Ciocia Ańdzia - tak autor listów określał umownie Wielką Brytanię (Anglię).

55 Turczynka - zapewne chodzi o Turcję.

${ }^{56}$ Sonia - chodzi prawdopodobnie o Sowiety (Związek Sowiecki).

57 „Głos Radziecki” - sowiecka gazeta polskojęzyczna wydawana w Kijowie, organ Komitetu Centralnego Komunistycznej Partii (bolszewików) Ukrainy, rozprowadzana była również na terenach Polski okupowanych przez Związek Sowiecki, w 1941 roku przestała wychodzić i to była przyczyna niedostarczania jej do łagru w Iwdelu.

58 Jaśko Baumgartner - Jan Baumgartner (1896-1941) był kołodziejem (stolarzem wozów), jego żona Bronisława i córka Elżbieta działały w „Sokole”, syn Otto Jan zginął 2 lipca 1941 roku podczas bombardowania Kut przez lotnictwo niemieckie. 
Potrzebuję więc ubrania na „gwałt”! U nas jeszcze zimno - śniegów po lasach dość - tak że po pas zapadamy się. Czuje się jednak już bliską wiosnę, bo słońce dobrze przygrzewa! U Was - zapewne już dawno wiosna nastała, i ludzie pracują po polach!?

Czy były jakieś wiadomości od Romków i Tadziów? Co jest z Kaziem, dziwi mię że się z nim nie widujesz, przecież można! Kiedy byłaś ostatni raz u niego względnie w Stan[isławowie]? Bardzo Was proszę piszcie do mnie często wszyscy po trochę. Dzieciaki - niech piszą oddzielnie. Myszki kartka w zdumienie mię wprawiła - do nich osobno piszę! Równocześnie piszę i do Jasienowa!

Następny list do Was wyszlę aż koło $7 / 5$, bo do 5/5 nie otrzymamy żadnych listów - więc nie wiem czy do mnie coś jest!?! Jeśli odemnie będą rzadkie wiadomości - nie dziwcie się - przychodzę zmęczony i pisać się nie chce! Dziś i jutro świątkujemy - a pozatem codziennie pracujemy od 6.30 do 6.30. Możliwe, że stąd wyjadę - wówczas nastąpi długa przerwa! Kończę mocno Was wszystkich ściskam i całuję. Dziadziowi rączki. Sianek

[poziomy dopisek odwrócony:] Dla wszystkich Krewnych i Znajomych serd[eczne] pozdrowienia.

[pionowy dopisek:] Czy dzieci dostały znaczki?

[pionowy dopisek na stronie 2:] W „Bułeczkach” małych lub rogalkach poślij z 30 rubli?

14.

Kochana Myszuchno!

Iwdel, 1/5 [1941].

Karteczkę Twoją otrzymałem razem z listem Mamusi. Cieszę się, żeś wysłała takową do mnie, sprawiła mnie ona wielką niespodziankę i wiesz co z nią zrobiłem, schowałem ją i od czasu do czasu czytam, przypatrując się Twoim kuszlawym literkom. Dziękuję Ci i Rysieńce za cukiereczki, pierniczki, bułeczkę i wogóle wszystko coście swojemi łapkami upiekły! Bardzo smaczne wszystko, lecz już się kończy! Kwiatuszki Twoje schowałem i jak Bóg pozwoli postaram się z nimi wrócić! Chciałbym bardzo Was wszystkich zobaczyć i uściskać. A możebyście mnie posłały swoją fotografję? Czyście były gdzieś w czasie świąt - no i jak spędziłyście święta? Czyście miały dużo dni wolnych? Czy Rysieńka pomaga Tobie w nauce? Od czasu do czasu załączam ładne znaczki dla Was - posłałem także i 2 kwiatki Iwdelskie z datą - ciekaw jestem czy dochodzą? Napisz mnie o wszystkiem, oraz czy jesteście zdrowe, czyście urosły - a jak z Twoimi warkoczami? Kończąc mocno Ciebie ściskam i całuję. Twój Tatuś. 


\section{5.}

Kochana Rysieńko!

Listy Twoje otrzymałem i mocno Ciebie całuję za takowe! Dlaczego tak mało i rzadko do mnie pisujesz? Myszka wysłała do mnie karteczkę - a czy Ty wyobrażasz sobie - jaką ta kartka sprawiła mnie niespodziankę i radość?!!! Jestem zdrów - pracuję i czekam niecierpliwie chwili kiedy się złączymy?! Tęskno mnie bardzo za Wami, chciałbym już Was zobaczyć i uściskać. Pisała mnie Mamusia, że ładnie się uczycie - i że jesteście grzeczne! Pamiętaj o tem Rysieńko - że swojem dobrem zachowaniem się, dobrą nauką i w ogóle jeśli będziesz posłuszną i grzeczną sprawisz Mamusi największą przyjemność, no a mnie? Nie masz pojęcia jak ja się cieszę jeśli Mamusia pisze o Was, że jesteście grzeczne i dobrze się uczycie! Korzystaj z fortepianu - szkoda tracić jeśli jest taka dobra sposobność. Czy dostałaś znaczki pocztowe, które w listach dołączam? Czy pomagasz czasem Myszce w nauce, a w jakich Wy klasach jesteście? Napisz do mnie obszerny list o wszystkiem! Kończąc mocno Ciebie ściskam i całuję. Twój Tatuś!

[pionowy dopisek:] Poprzednio posłałem Wam 2 znaczki.

16.

Kochany Dziadziu!

Iwdel 3/5. [19]41.

W dniu imienin przesyłam Dziadziowi Najserdeczniejsze Życzenia, przedewszystkiem czerstwego zdrowia, by przetrwać nawałnicę wojenną. Przepraszam bardzo za takie pismo, ale czynię to w polu na kolanie!

Po 2 dniach wolnych od pracy - znów jesteśmy w lesie i ścinamy drzewo. Śnieg duży - w nogach mokro i ognisko nie pomaga!

Trzymaj się Dziadziu mocno, byśmy się zobaczyli w innych warunkach.

Kończąc mocno ściskam i rączki całuję. Sianio

17.

Kochane Moje Dzieciaki!

Iwdel 7/5. [19]41.

Dziś 7/5 - dzień Waszych urodzin! Chociaż jestem bardzo daleko od Was - myślami stale jestem koło Was pieszczotki i mimo, że przyszedłem z pracy mokry i zziębnięty - zabrałem się do pisania tego listu - z Wami wziąc udział w rozmowie! Nie wiem jakie niespodzianki spotkały Was w dniu dzisiejszym - odemnie przyjmijcie Najserdeczniejsze Życzenia - przedewszystkiem szczęścia i pomyślności w Życiu Waszem - a do tych słów dołączam Wam 2 kwiatki z datą Iwdel $7 / 51941^{59}$.

${ }^{59}$ Dołączone do listu kwiatuszki i listeczki z Uralu zachowały się do dziś. 
Ja jestem jako tako zdrów. - A co Wy porabiacie? Czyście zdrowe? Napiszcie mnie zaraz duży list, tu muszę Wam donieść, że od 28/4 - (wtedy dostałem list z 7/4) nie mam żadnej od Was wiadomości! Nie rozumię dlaczego? Powiedzcie Mamusi - że jestem zły za brak listu i dlatego nic do Mamusi nie piszę!

Czekam od Was wiadomości, a kończąc - mocno Was ściskam i całuję - Wasz Tatuś.

PS. Dla braku czasu nic więcej nie piszę - czekam listu z domu!

Mocno wszystkich ściskam i całuję - Dziadziowi rączki. Sianio

18.

Najdrozsi!

Iwdel 8/5. [19]41.

Przykro mnie bardzo, że od Was nie otrzymałem już od dłuższego czasu żadnej wiadomości. Ostatni list Wasz z 7/4. - Co od tej daty dzieje się u Was nie wiem? Dzisiaj dostałem list od Kajcia - pisze mnie o jakichś pieniądzach ze Stanisławowa oraz że dołącza do listu swojego z 14/4. (zdaje mnie się 100 rb) coś - co jednak nie wiem - bo wymazane i zabrane!!! Tyle razy prosiłem, by w listach - ani paczkach pieniędzy nie posyłać. Bułeczki małe lub rogalki mogą być, a w nich ban! ${ }^{60}$. Wczoraj napisałem list do dzieci - ciekaw jestem czy dostały? Co Wy porabiacie jak ze zdrowiem? Napisz mnie dlaczego powstała taka przerwa w pisaniu? Napiszcie mnie dokładnie o wszystkiem - tyle przecież różnych pytań pisałem, a odpowiedzi żadnej! Aha! Ponieważ Kajcio skarży się na ciężkie obowiązki - napisałem by mnie nic nie posyłał - a Wam też! Kończąc mocno Was wszystkich ściskam i całuję. Dziadziowi rączki. Sianek.

[pionowy dopisek:] Napisz mnie co słychać [w] Waszych stronach.

19.

Najdrozsi!

Iwdel 12/5. [19]41.

Jestem bardzo niespokojny o Was, gdyż od dłuższego czasu nie mam od Was żadnej wiadomości! Ostatni list, który otrzymałem z końcem kwietnia, pisany przez Ankę 7/4 - był listem, który mniej więcej razem z pakunkiem nadszedł i od tego czasu - nic!!! Nie mogę tego zrozumieć - co jest właściwie na rzeczy i jaka tego przyczyna? Nie wyobrażacie sobie jak czekam na wiadomości z domu, jak uganiam po powrocie z lasu po biurach za pocztą, a gdy otrzymam odpowiedź negatywną - wprost z płaczem odchodzę do baraku.

${ }^{60}$ Ban - chodzi o pieniądze, z rum. ban - drobna moneta. 
Wysłałem do Was listy z daty $3 / 4-5 / 4-12 / 4-16 / 4-1 / 5-3 / 5-7 / 5-8 / 5$ i dzisiejszy. Na te listy nie mam potwierdzenia!!!? W tej chwili dostałem rozkaz zbierać się na etap ${ }^{61}$.

Odjeżdżamy gdzieś nie wiadomo dokąd? Przerywam już list, mocno Was wszystkich ściskam i całuję. Sianek.

\section{0.}

\section{Najdrozsi!}

Iwdel 15/5 41.

Wczoraj odebrałem Waszą paczkę - list polecony z 15/4, w którym był dopisek Myszki. Wszystko doszło w porządku, w całości - tak jak i w poprzednich paczkach. Za przesyłkę serd[ecznie] dziękuję. Wszystko bardzo smaczne, dobre a najlepsze 2 rogalki, które jedne z pierwszych poszły na pożarcie.

Dnia 12/5 wysłałem list, który przerwałem, wskutek zarządzenia wyjazdu na etap. - W nocy odwołano i na razie pozostajemy na miejscu.

Ponieważ jest ciemno, więc dużo pisać nie mogę - w każdym razie ogółem donoszę, że w paczkach wszystko w całości doszło i zostało przeze mnie i przy pomocy innych skonsumowane! Zapytujesz mię Anko o jasiek i prześcieradło więc piszę byś mnie prócz 2 lub 3 koszul nic więcej z rzeczy nie posyłała - nie mam gdzie to trzymać - a obawiam się, by nie spotkało mię jeszcze raz to, co już raz miało miejsce, bo to jest na porządku dziennym.

Z listu pisanego 15/4 poleconego - i ze Stanisławowa z 23/4 (który otrzymałem 13/5) wnioskuję żeście dostali mój list z 3 i 12/4, a co się stało z listami z 5/4 - 16/4 - 1/5 - 3/5 -12/5. Wypiszcie mnie dokładnie daty odebranych listów. Czy dzieci dostały list i Dziadzio?

Najdrozsi! Wracam jeszcze raz do przesyłek - wszystkie już odebrałem, ostania poświąteczna, która przyszła równocześnie z paczką Cioci Hali ${ }^{62}$. Od Cioci Cesi otrzymałem kartkę - że także wkrótce poszle posyłkę. Do nich piszę równocześnie już z góry dziękując za wszystko - a Kajcio dołączył skarpetki - dwie chusteczki i mydełko.

Jak już napisałem pieczywo dzieci bardzo mnie smakowało - jak również orzechy - cukierki - no a kwiatuszki schowałem! Czy one dostały moje kwiatki i znaczki pocztowe?

Do nich teraz nie piszę, bo późno i ciemno!

W liście z 12/5 doniosłem, że wyjeżdżam. Rozkaz odwołano i dobrze się stało, bo byłbym ani paczek ani listów już nie odebrał. Listy wysyłane w paczkach odbierałem wszystkie, prócz jednego dużego, o którym zaraz doniosłem! Imnie

\footnotetext{
${ }^{61} \mathrm{Tj}$. do transportu w inne miejsce uwięzienia.

${ }^{62}$ Hala, Halszka - Helena z Ohanowiczów Kowalska, szwagierka autora listów.
} 
wydano - lecz w przyszłości nie posyłajcie - tylko osobno. Ban świetnie smakowało, dobre było do zjedzenia i w przyszłości tak posyłajcie. Trzewiki jeszcze nie nosiłem trzymam na inną chwilę. Jak Dziadziowi dopisuje zdrowie, bo wspomniałaś, że był niedysponowany? A w ogóle co Wy porabiacie - czy nie możecie mnie napisać cokolwiek o Cioci Gerze i innych. Czy słyszeliście, że syn wuja Adolfa Hesio ${ }^{63}$ wyjechał do Cioci Ańdzi? Wprost miał uciec ze swego domu?! A czy to prawda, że nasi przyjaciele zabierają do siebie młodych i starych na zabawę - jaką szykują Cioci Gerze? ${ }^{64}$. Napiszcie mnie coś o tem, bo jestem ciekaw? Również napiszcie, co inni porabiają w Kutach i po całym świecie - czy są zdrowi i czy pisują? Aha! Czy to prawda, że Ciocia Gera jest konająca? Napiszcie dokładnie!

Ja trzymam się i proszę $\mathrm{P}$ [ana] $\mathrm{B}$ [oga] o rychły powrót. Tymczasem chodzę do lasu na roboty i zmordowany wracam. Proszę Was bardzo - jeśli coś posyłacie to zawsze czosnyk i cebule załączcie. Nabazgrałem dużo lecz może nie o wszystkiem, jest już godzina 11ta i idę spać. I Wam życząc dobrej nocy przesyłam zarazem mocne uściski i ucałowania - dla Dziadzia ucałowania rączek. Sianek

21.

Iwdel 15/5.

Kochane Moje Dzieciaki!

W ostatniej chwili skreślam i do Was słów kilka. Dziękuję Wam za wszystko coście mnie upiekły i posłały. Bardzo mnie to smakuje a rogaleczki najlepsze. Kwiatuszki dostałem również i schowałem!

Myszuchno! Nie dziw się, że nie piszę często a szczególnie osobno do Was wierzcie mnie moje Kochane, że nie mogę - bo przychodzę zmęczony i mokry. Może P[an] B[óg] da, że długo trwać to nie będzie i zobaczymy się wkrótce. Proście mocno Wasze Patronki o pomoc dla nas!

Piszcie dzieci do Tatusia, bo bardzo tęsknię za Wami czekam na Wasze listy.

Kończąc - mocno Was ściskam i całuję. Wasz Tatuś.

${ }^{63}$ Hesio, syn wuja Adolfa - chodzi o Rudolfa Hessa, zastępcę Adolfa Hitlera i formalnie trzeciego (po Hermannie Göringu) przywódcę nazistowskich Niemiec. Będąc zwolennikiem zawarcia pokoju na Zachodzie, odbył on 10 maja 1941 roku samodzielny lot samolotowy do Wielkiej Brytanii z nadzieją nawiązania rokowań, ale został tam aresztowany, zaś Hitler odciął się od jego misji, uznając go za zdrajcę stanu.

${ }^{64} \mathrm{Tj}$. ofensywę przeciw Niemcom. 


\section{Najdrozsi!}

Iwdel 18/5. [19]41.

Wykorzystując - pierwszy dzień wolny od pracy - za cały czas pobytu mego w łagrach (pomijam 1 i 2 maja) i to tylko od południa - zabieram się do pisania listu. Piszę do Was wszystkich. Oprócz tego do Wysockiego ${ }^{65}$, z którym utrzymuję kontakt, oraz napisałem dzisiaj do Kut do Rö[m]era ${ }^{66}$. Jego pytałem o różne wiadomości kuckie i ogólne. Mimo, że Wysoccy zmienili adres - list mój doszedł i otrzymałem odpowiedź! Doniósł mnie, że zjeżdżają do niego córka i ciotka, które były w Irkucku ${ }^{67}$. Głód, nędza i wszy dokuczają im jak poprzednio. - Cóż zrobić - trudno im pomóc - gdy człowiek sam w kłopotach! Przed trzema dniami tj. zaraz po otrzymaniu paczki od Was i listu Anki z 15/4 wysłałem list obszerny. W nim o wszystkiem napisałem - tu jednak jeszcze napomknę, że wszystkie paczki doszły w porządku, że wszystko jest bardzo smaczne, a szynka (dziwię się okropnie) doszła bez zepsucia, po miesięcznej jeździe! Najdrozsi! Jestem dziadziowi bardzo zobowiązany za opakowanie a Wam wszystkim ślicznie dziękuję i mocno Was całuje za każdy przysmak - które pożeram a nie zajadam. Opiszę Wam co jadam: Rano - zupa woda - postna i to o ile gotowana nie na rybach - kipiatok lub jak jest czas herbata - i kawałek chleba. - o 7mej rano w las i tam do 6 wiecz[orem]. Bez obiadu. Kolacja o 7mej (godzina marszu z lasu). Jeśli podobna do śniadania nie jem. Kaszę - o ile dadzą - zjadam. Tego jest tyle co kot napłakał! Natomiast śledzi mam po uszy - rano i wieczorem raczą nas tym czego nie jem. Wieczorem piję 3 garnuszki herbaty i chrupię suchary. Obecnie zmieniliśmy barak na jeszcze gorszy i ani gdzie usiąść, ani gdzie spać - bo brudny - a oprócz tego wszy i pluskwy dokuczają wysysając resztki krwi - którą inni nie wyssali. Nie piszę o tem dlatego, bym się tu tak źle czuł, postanowiłem wszystko przetrzymać i jestem „przy nadzieji” że wkrótce wszystko się zmieni. Dobra nadzieja i myśl ciągła o Was - trzyma mię na duchu i Bóg da, że skończy się nasza męka! Co wy porabiacie? Czy jesteście wszyscy zdrowi? Czemu od wszystkich nie ma dopisków! Nie posyłajcie mnie tytoniu drogiego. Proszę o machorkę krupnistą po 35 kop. lub papierosy machorkowe. Praporów 2 pudełeczka ${ }^{68}$, by dać komuś! Dużo czosnku, cebuli (jedyny środek przeciw szkorbutowi), bryndza, powidło,

${ }^{65}$ Wiktor Wysocki - notariusz, a w latach 1934-1938 burmistrz Kut.

${ }^{66}$ Paweł Römer - aptekarz kucki wyznania mojżeszowego, po wejściu Niemców do Kut i rozpoczęciu przez nich akcji likwidacji Żydów (1942) uniknął śmierci z rąk kolaborantów ukraińskich dzięki pomocy niemieckiego żołnierza; ukrywał się m.in. w domu lekarza Zbigniewa Tustanowskiego, po wojnie wyjechał do Wrocławia, a stamtąd do Izraela i zamieszkał w Hajfie.

${ }^{67}$ Córka Wiktora Wysockiego, Jadwiga (ur. 1916), aresztowana była w 1940 roku i zesłana, ale nie do Irkucka na Syberii, lecz do Ust' Wiled' w obłasti archangielskiej, skąd została faktycznie zwolniona, przy czym wyjechała dopiero we wrześniu 1941 roku.

${ }^{68}$ Chodzi o papierosy sowieckie Krasnyj prapor. 
suchary, rogalki, to konieczne. Tłuszcz i cukier - jedyne co trzyma człowieka. Ciekaw jestem bardzo - czy tam drogie są wędliny? Duszyczko tak się urządzaj by na niczem Wam nie zbywało - sprzedawaj wszystko - a pamiętaj drogo i żyjcie jak dom tego wymaga. - Napiszcie mnie ogródkami co słychać, - a przytem o sobie krewnych i znajomych?

Ja jeszcze jestem tu, kiedy pojedziemy gdzieś - nie wiadomo - może do domu???

Czekam bardzo obszernej wiadomości.

Kończąc mocno Was wszystkich ściskam i całuję - Dziadziowi rączki a „bączka” specjalnie za to, że przynosi listy i nadaje paczki. Sianek

23.

Kochana Myszuchno!

Iwdel 18/5. [19]41.

Znowu piszę dzisiaj do Was - mimo, że jesteście mnie dłużne kilka odpowiedzi! Jak już pisałem Twój list z 16/4 otrzymałem z listem Mamusi. Dziękuje Wam moje szczebiotki, że od czasu do czasu coś napiszecie - lecz pamiętaj, że to mało - chcę dostawać listy co dnia! Wyobraź sobie, ze Tatuś jest tak daleko od Was, bo coś 5 tyś. klm. że bardzo tęskni za Wami i że jedynie listy i wiadomości od Was i o Was przynoszą ulgę!

Pytasz mnie w liście, czy otrzymałem paczki, i te rzeczy, które Wy upiekły. Wszystko doszło w porządku i mocno Was za rogaleczki i inne przysmaki ściskam.

Pamiętaj Myszuchno, żeś obiecała w jednym liście pisać często, ja też na to czekam.

Co porabiasz Myszuchno, czy jesteś zdrowa i jak się uczysz? Przypuszczam, że nie bardzo dobrze, jeśli „,dopiero” jesteś w II klasie?

Ja jestem niby zdrów, trzymam się dobrze, mam nadzieję, że się niezadługo zobaczymy! Zaraz po otrzymaniu mojego listu odpisz mnie!

Kończąc - mocno Ciebie ściskam i całuję

Twój Tatuś.

P.S. Dla Musi serd[eczne] pozdrowienia

$\mathrm{Pa}$ ! Moja Szczebiotko. Pa!

24.

Kochana Rysieńko!

Iwdel 18/5. [19]41.

Karteczkę Twoją z 1/5 otrzymałem 16/5 i wykorzystując dzisiejsze popołudnie wolne od pracy zabieram się do rozmowy z Wami! Piszę do Mamusi, do Ciebie 
i Myszki, abyście mieli co czytać. Za karteczkę Tobie dziękuję i mocno całuję! Ponieważ zapytujesz o niejedno, więc też Tobie odpowiem. Jak już poprzednio pisałem mieliśmy 1 i 2 maja dzień wolny od pracy - nigdzie nie chodziliśmy bo nam nie wolno! Dzisiaj pierwsza „niedziela” jako dzień wypoczynku i to od południa - wogóle za cały czas jak długo tu jestem! Pakunki wszystkie otrzymałem, ostatni poświąteczny i chociaż już pisałem jeszcze raz wspomnę, że doszło wszystko w całości i jest bardzo smaczne - szczególnie Wasze rogaleczki!

Co Ty Rysieńko porabiasz? Czy jesteś zdrowa? Grzeczna i czy Mamusi pomagasz? Pisz często do Tatusia - to mię uspokaja - bo bardzo tęsknię za Wami!!!

Kończąc mocno Ciebie ściskam i całuję. Twój Tatuś.

$\mathrm{Pa}$ ! Moja Ty pieszczotko - $\mathrm{Pa}$ !

\section{5.}

\section{Najdrozsi!}

Iwdel 28/5. [19]41.

Kartkę Anki z 5/5 otrzymałem 24/5 - równocześnie z kartką Kajcia z Jas[ieniowa] pisaną przez Tolka, który był u niego. Między innemi, doniósł, że 6/5 ma doręczyć paczkę Kaziowi! Nie odpisywałem Wam prędzej bo codzienna praca i ciągłe deszcze całodzienne tak mordują - że nie byłem w stanie list wysłać. Teraz piszę - bo muszę Was zawiadomić, że już stąd odjeżdżam - dokąd nie wiem, mówią, że bardzo daleko i droga potrwa około 6 tygodni.

W każdym razie zaraz po przyjeździe napiszę - a Wy tymczasem wstrzymajcie się z wysyłkami listów i paczek. Jest godz. 12 w nocy, czekałem, aż inni usną bym napisał ten list. Jak mi jest obecnie na sercu - wyobrażacie sobie, na myśl, że z Wami zerwę kontakt może na 2 lub 3 mies. łzy cisną się do ócz. Moim drogim pieszczotkom załączam ostatnie, zerwane na Uralu - w Iwdelu, kwiatuszki - które ukazały się zaraz po zniknięciu śniegu!

Dla Was wszystkich ostatnie stąd pozdrowienia! Jedziemy znowu w nieznane i tak się tułamy jak Wieczny Żyd w skrajnej nędzy itd. Co za pech! - Tu, człek obeznał się z ludźmi i stosunkami, a co najważniejsze, że tu odbierałem pocztę, na którą z takiem utęsknieniem wyczekiwałem, i już ruszaj dalej - bo gonią!!!

Żal mi również tych paczek, które mnie nie zastaną - a los ich znany. Z listami ten sam porządek!

Najdrozsi Moji! Co porabiacie, czy jesteście zdrowi? Co z moją prośbą czy jest jaka nadzieja? Co porabia Kazio - jak się czuje? A co inni? Co słychać u Was - może coś weselszego jak koło nas?

Bardzo Was proszę, po otrzymaniu mojego adresu odwrotnie odpiszcie!

Czy otrzymaliście mój list z 5/4. Bo nie mam potwierdzenia, a wzmianka już jest o liście z 16/4.

Kończę - a na dobranoc wszystkich Was mocno ściskam i całuję - Dziadziowi rączki - Sianek. 
26.

2/6. [19]41. [nadane jeszcze w Iwdelu, stempel na kopercie]

Najdrozsi!

Już - jak doniosłem Wam od 28/6 ${ }^{69}$ jestem w drodze. Znajduję się na punkcie przejściowym i za 2 do 3 dni stąd odjedziemy. Mówią rozmaicie. Jedni, że jedziemy na Sybir, inni, na Murmań ${ }^{70}$ lub do Kazania ${ }^{71}$.

Jedno - pewne - podróż czeka nas długa - uciążliwa - pocieszam się, że może bliżej świata - do Europy! Dnia 28/6 ${ }^{72}$ wysłałem do Was list z Iwdelu - ostatni! Żal mi, że na długo przerywam kontakt z Wami. Drugie zło - że wyszedłem zupełnie z zapasów, nie mam nic - a chleba brak! Dostałem wiadomość z Horodenki, że Ciocia Cesia wysłała po 5/5 paczkę. Ciekaw jestem, czy kiedyś ją otrzymam?! - List Anki - względnie kartka, była z 5/5. Od tego czasu nie dostałem nic. Jestem niespokojny co z Wami jest, czyście zdrowi - co porabiacie. Z niecierpliwością wyczekiwałem odpowiedzi na moje pytania w ostatnich listach a tu nastąpi taka długa przerwa? To dla mnie okropne! Gdybym mógł coś z drogi napisać - wykorzystam - jeśli nie - to już z miejsca - gdzie się zatrzymamy! Brakiem odemnie wiadomości nie denerwujcie się, bo tylko brak sposobności będzie przyczyną! Jestem tak silnej wiary i dobrej nadzieji, że Bóg pozwoli nam się widzieć, i żadna mitręga, ani praca nie doprowadzi mnie do wykończenia się! Trzymajcie się Wy zdrowo i mocno - o mnie nie martwcie się - nademną czuwa Patronka naszych Dzieci - którą codziennie proszę o zdrowie i pomoc dla Was!

W najbliższym liście Waszym proszę mnie dokładnie napisać o wszystkiem oraz jakie listy od 5/5 do ostatniego czasu mnie wysyłaliście! Proszę Was bardzo przygotujcie dla mnie dużo skwarków i innych rzeczy oraz „rogalków” bo wygłodnieję mocno! Nie wiem, czy nie możnaby więcej nadawać jak $8 \mathrm{~kg}$. To zależy od poczty kosowskiej, jeśli przyjmie - tu wydadzą. Prócz koszul, o które prosiłem nic mnie więcej z bielizny nie posyłajcie. Czy dostałaś susz od Domińka? Może powidła gdzieś dostaniesz - ale chciałbym by było przerobione z konfiturą ożynową. Skwarki, dobrze by przetopić - wlać do garnka glinianego i tak wysłać. Będę miał i smalec i skwarki do mąki! Mąka teraz się wykańcza - bo gotuję po dwa razy dziennie mamałygę i tem się dożywiam. Jem samą. Bardzo smakuje - bo od rana do wieczora nic nie dostajemy! Pieniędzy nam nie wypłacono! Co z niemi będzie nie wiem? Upomnę się o nie - już z nowego miejsca. Aha! Z tytoniu proszę o papierosy machorkowe i tytoń machorkę! Droższych mnie nie posyłajcie! Wiem, że sami już troszczycie się o wysyłki - więc nic nie będę pisał co macie posyłać! Co można - chętnie i mile widziane!

69 Oczywista omyłka, chodzi o 28 maja.

${ }^{70}$ Murmańsk - port nad Zatoką Kolską w Rosji, w pobliżu granicy z Norwegią i Finlandią.

${ }^{71}$ Kazań - miasto w Rosji, przy ujściu rzeki Kazanki do Wołgi, stolica Tatarstanu.

72 Oczywista omyłka, chodzi o 28 maja. 
Duszyczko! Do Ciebie się zwracam. Rób tak, by w domu nic nie brakowało a dopiero później dla mnie. Uważaj na dzieci - bardzo się martwię - by ich coś nie spotkało!

Ciocię Pietrunię przeproś, że nie wysłałem życzeń.

Kończąc wszystkich Was mocno ściskam i całuję Dziadziowi rączki - dla innych pozdrowienia. Wasz Sianek.

\section{7.}

\section{Najdrozsi!}

Dnia 8/6 1941 [Jekateryninka ${ }^{73}$ ]

Do dnia dzisiejszego jestem na punkcie przesiedleniowym i czekamy dalszego rozkazu! Gdzie nas wyszlą - nie wiadomo - jak już napisałem Wam przedtem - mówią - że daleko! Z tego miejsca wysłałem do Was list z 2/6 - ciekaw jestem, czy dostaliście? W tamtym, wspomniałem, że nie mam od Was żadnej wiadomości już od 5/5 tj. ostatniej kartki napisanej przez Ankę. Wyobraźcie sobie moje zdenerwowanie brakiem wiadomości od Was przez przeszło miesiąc! Jestem bardzo niespokojny o Was - nie wiem czy żyjecie - czyście zdrowi - co porabiacie i jak w ogóle żyjecie? Ten niepokój i troska bardzo mię przygniatają, oprócz innych jeszcze dolegliwości, które codziennie bądź powtarzają się - bądź też zmieniają i pojawiają się $\mathrm{w}$ innej formie. Chciałbym bardzo $\mathrm{z}$ tego $\mathrm{xxxxxx}^{74}$ chaosu wyrwać się i choć przez chwilę z Wami być, by Was zobaczyć, z Wami porozmawiać. Trudno, o tą małą chwilkę - trudno się jej doczekać i nie wiem kiedy to nastąpi? Jak się przedstawia sprawa wniesiona przez dzieci - czy jest jaka nadzieja dobrego załatwienia? Możeby poruszyć znowu - wszystkie środki wykorzystać - by cel osiągnąć! A jak przedstawia się sprawa Kazia? Co z nim jest - czy zdrów - i czy dojeżdżasz do niego? Staraj się Anka o widzenie się z nim - myślę - że pozwolą! Czy od Romków i Tadziów są jakie wiadomości? Co porabia ciocia Pietrunia czy mieszka sama - co Krzysiowie, Kolowie, inni z Kut - Kasunia - Miecia - Chaberscy? Czy byłaś w Kutach u Agops[owiczów] - i czy wręczyłaś jej 5 rubli - które pożyczyłem od jej ojca. Niech ona jemu odeszle - bo ja nie znam jego adresu. Jaśka - co też zabrali nie wiem gdzie jest! A co porabiają Jańkowie - pozdrówcie wszystkich odemnie. Czy Haneczka dalej pracuje? Co wogóle słychać u Was - jak się układają sprawy familijne? jak się zachowują sąsiedzi - czy nie kłócą się - a może dochodzi do bójek? Napiszcie mnie o wszystkiem na podany adres, może jeszcze mię tu zastanie list. Paczek nie posyłajcie - dopóki nie napiszę! Kończąc mocno - bardzo mocno Was wszystkich ściskam i całuję - Dziadziowi rączki

Wszyscy coś napiszcie! Sianek

73 Według stempla na kopercie. Jekateryninka - przysiółek, położony w leśnej okolicy około 30 kilometrów na południe od miasta Iwdel.

${ }^{74}$ Skreślony wyraz. 
28.

Kochana Rysieńko! Dnia 8/6. 1941.

Już bardzo dawno nie mam od Was i o Was żadnej wiadomości! Nie wiem może i pisałaś coś do mnie - ja jeszcze nic nie otrzymałem - a w ogóle od 5/5 nie otrzymałem od Was żadnego listu. Teraz ja jestem na wyczekiwaniu dalszej podróży. Napisz jednak coś do Tatusia pod podanym adresem - może jeszcze ten list dojdzie. Wioska, w której jesteśmy - jest taka mała i dzika - że prócz lasów, nic tu nie widać! Pytałem się o nazwę tej wioski - ale ona się nie nazywa!!!

Co ty Rysieńko porabiasz - czyś zdrowa - jak się uczysz - kiedy wakacje u Was rozpoczną się? Napisz mnie o wszystkiem obszernie - chcę czytać listy od Was jak najdłużej.

Do Myszki piszę osobno. Czyście dostały moje listy do Was specjalnie pisane, a na które ja żadnej odpowiedzi od Was nie dostałem!

Czekam listu - ale odwrotnie a teraz mocno Ciebie, moja Rysieńko - moje Ty serduszko ściskam i całuję - ale to bardzo mocno.

Twój Tatuś

\section{Bibliografia}

\section{Źródła}

Archiwum Fundacji Kultury i Dziedzictwa Ormian Polskich w Warszawie: Zbiór kopii archiwaliów, sygn. 9

Archiwum Romany Obrockiej w Obornikach Śląskich: relacje T. Płytyczowej i A. Stefanowiczowej

\section{Opracowania}

Bakanacz J., Mostowicz (Dotęga-Mostowicz) Tadeusz, w: Polski słownik biograficzny, 22, Warszawa-Wrocław-Kraków-Gdańsk 1977, s. 62

Dzwonkowski R., Leksykon duchowieństwa polskiego represjonowanego w ZSRS 1939-1988, Lublin 2003

Kasprowicz B. S., Teresa z Donigiewiczów Płytyczowa, „Awedis”, 21, 2014, s. 9

Mazur G., Pokucie w latach drugiej wojny światowej. Położenie ludności, polityka okupantów, działalność podziemia, Kraków 1994

Nicieja S., Kresowa Atlantyda. Historia i mitologia miast kresowych, 6, Stryj, Kuty, Rybno, Baniłów, Kniaże, Załucze, Opole 2015

Obrocka R., Issak Antoni Donigiewicz, „Awedis”, 18, 2014, s. 10

Zaleski T., Stownik biograficzny księży ormiańskich i pochodzenia ormiańskiego w Polsce w latach 1750-2000, Kraków 2001

Zbrodnicza ewakuacja więzień i aresztów NKWD na Kresach Wschodnich II Rzeczypospolitej w czerwcu-lipcu 1941 roku. Materiaty z sesji naukowej w 55. rocznice ewakuacji więźniów NKWD w głąb ZSRR, Łódź, 10 czerwca 1996 r., red. J. Mikoda, Warszawa 1997 


\section{Netografia}

http://wiki.ormianie.pl/index.php?title=Issak_Antoni_Donigiewicz\&redirect $=$ no https://kresy-siberia.org/hot/?nagranie=wiewolw\&lang $=$ pl

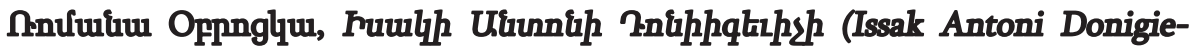

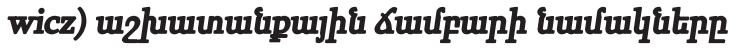

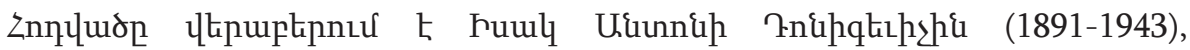

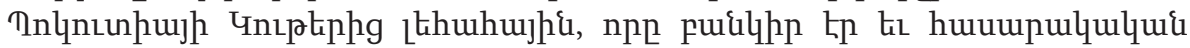

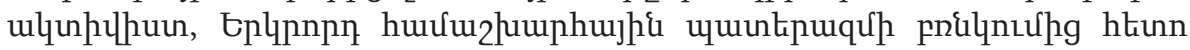

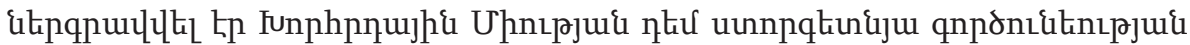

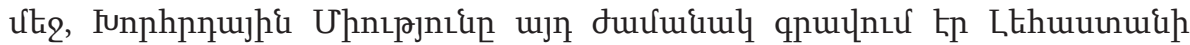

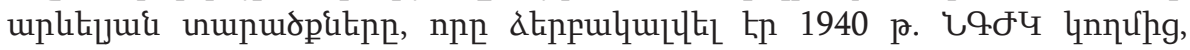

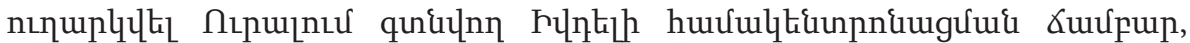

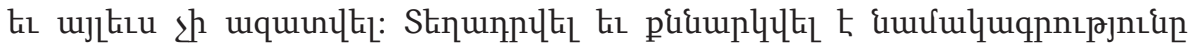

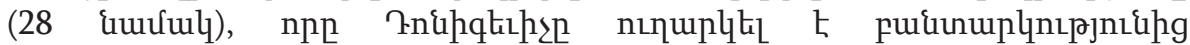

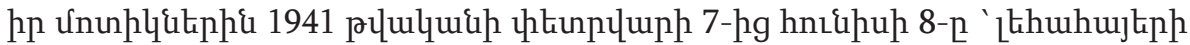

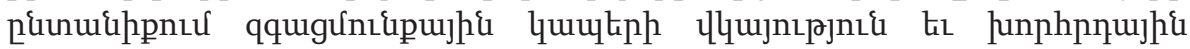

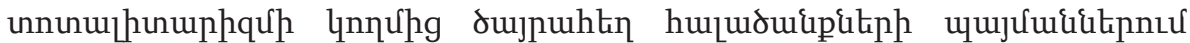
uwnplqujhi wihuunp uqupunp:

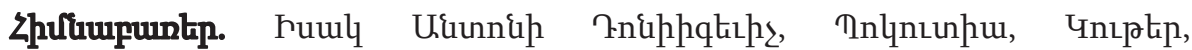

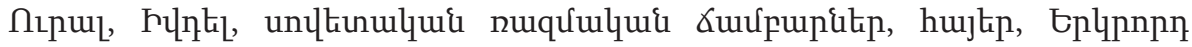

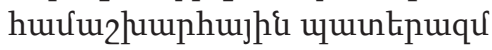

\section{Romana Obrocka, Issak Antoni Donigiewicz's Letters from a Soviet Prison Camp}

The article focuses on the story of Issak Antoni Donigiewicz (1891-1943), a Polish Armenian born in Kuty in the region of Pokucie (Pokuttia), who was a banker, restaurateur and social activist. Following the outbreak of the Second World War, he became involved in underground activities against the Soviet Union which at that time occupied the territory of Eastern Poland. In 1940 the NKVD (People's Commissariat for Internal Affairs) arrested Donigiewicz and sent him to a Soviet prison camp in the Urals (Ivdel) where he would spend the rest of his life. The author has included and examined the original correspondence (28 letters) sent by Donigiewicz to his loved ones in the period from $7^{\text {th }}$ February to $8^{\text {th }}$ June 1941 . The letters stand as a moving testimony to the emotional bonds within the Polish Armenian family and the struggle of an individual to survive under conditions of extreme persecution during the Soviet totalitarian regime.

Keywords: Issak Antoni Donigiewicz, Pokuttia, Kuty, the Urals, Ivdel, Soviet prison camps, Armenians, World War II 


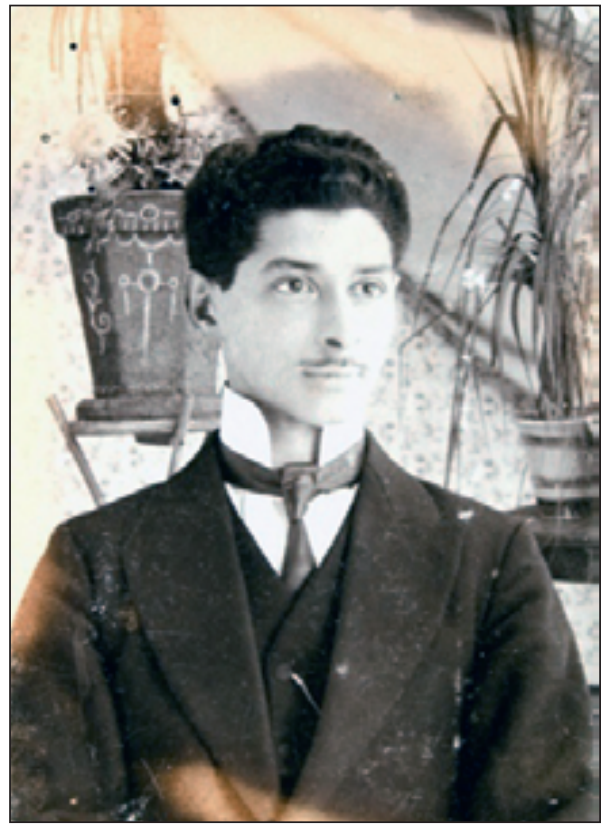

Issak Antoni Donigiewicz za młodu, Fundacja Kultury i Dziedzictwa Ormian Polskich w Warszawie

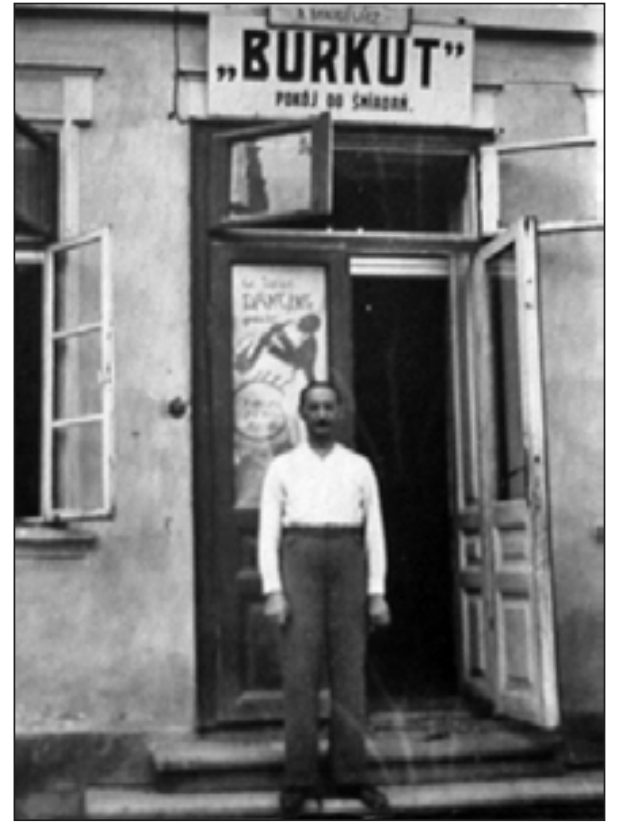

Issak Antoni Donigiewicz przed swą kucką restauracją Burkut, Fundacja Kultury i Dziedzictwa Ormian Polskich w Warszawie

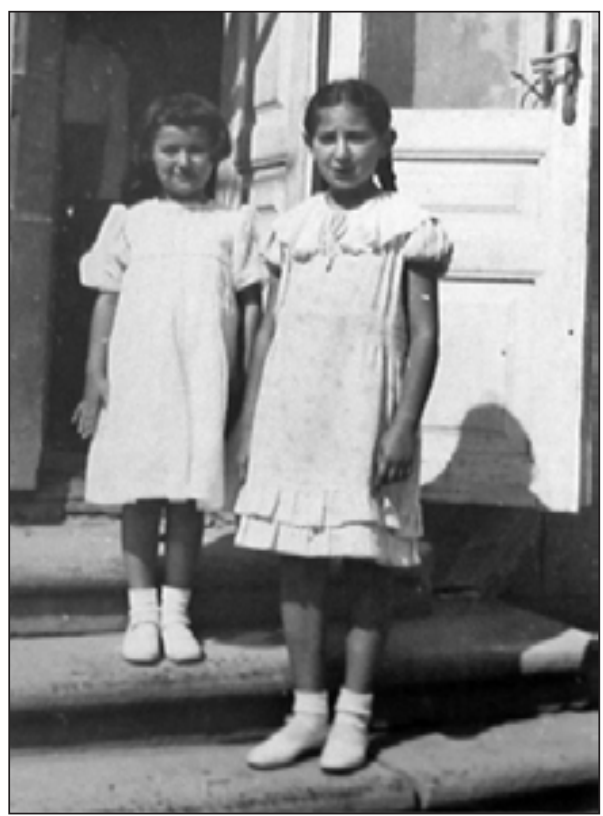

Teresa i Maria Donigiewiczówny, córki Issaka, na schodkach jego restauracji, Fundacja Kultury i Dziedzictwa Ormian Polskich w Warszawie 


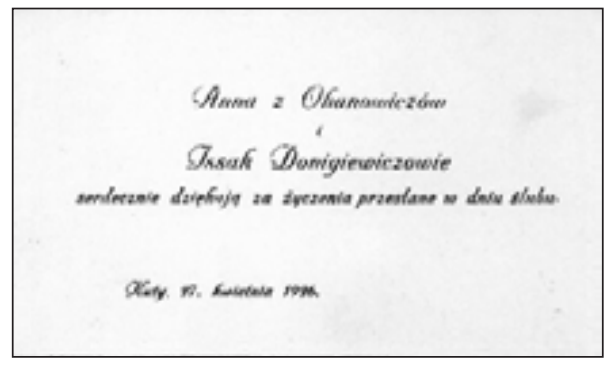

Podziękowanie za życzenia ślubne Anny z Ohanowiczów i Issaka Donigiewiczów, zbiory rodzinne

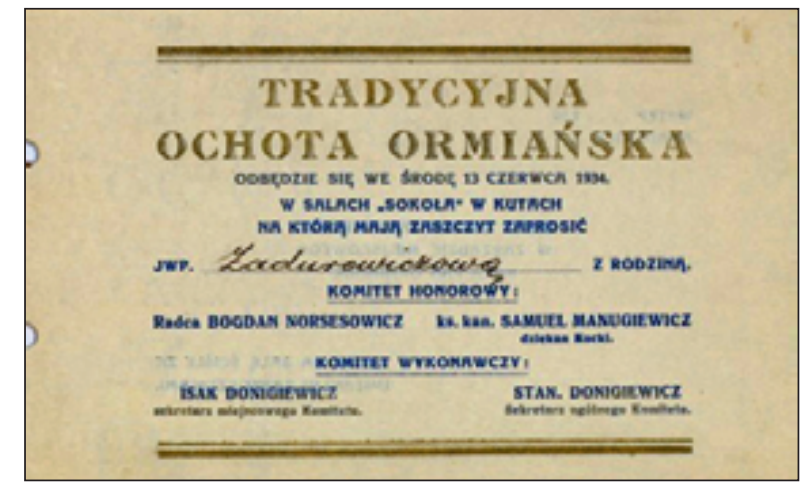

Zaproszenie na ochotę ormiańską w Kutach, Fundacja Kultury i Dziedzictwa Ormian Polskich w Warszawie

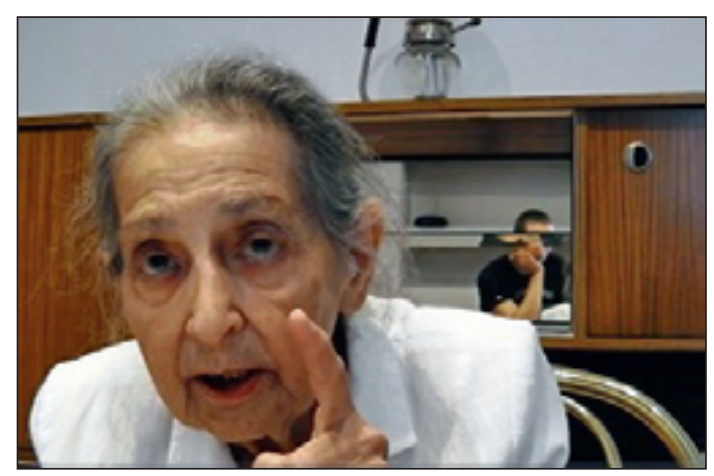

Teresa z Donigiewiczów Płytyczowa (1927-2014), Bytom, 2012, fot. R. Obrocka 


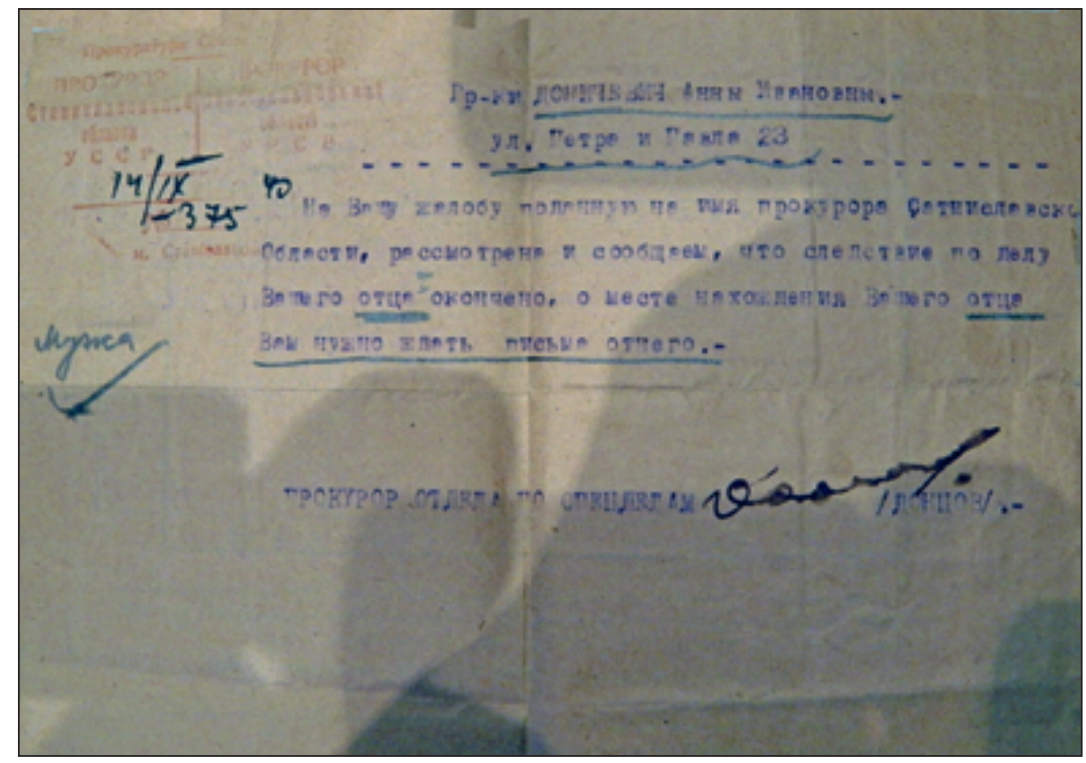

Pismo sowieckiej prokuratury informujące Annę Donigiewiczową o zakończeniu śledztwa w sprawie jej męża, mylnie nazwanego tu ojcem, i zapowiadające nadejście listu od niego, 14 września 1940, Fundacja Kultury i Dziedzictwa Ormian Polskich w Warszawie

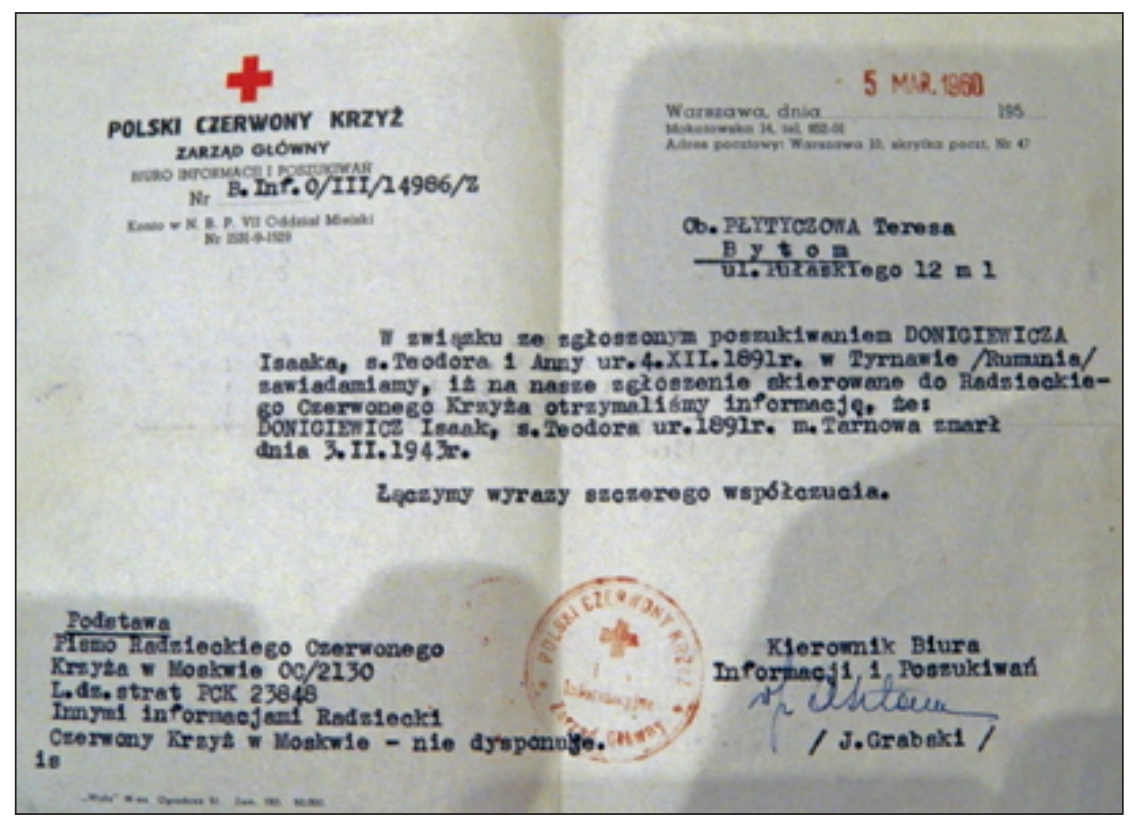

Informacja Polskiego Czerwonego Krzyża o śmierci Issaka Donigiewicza, Fundacja Kultury i Dziedzictwa Ormian Polskich w Warszawie 


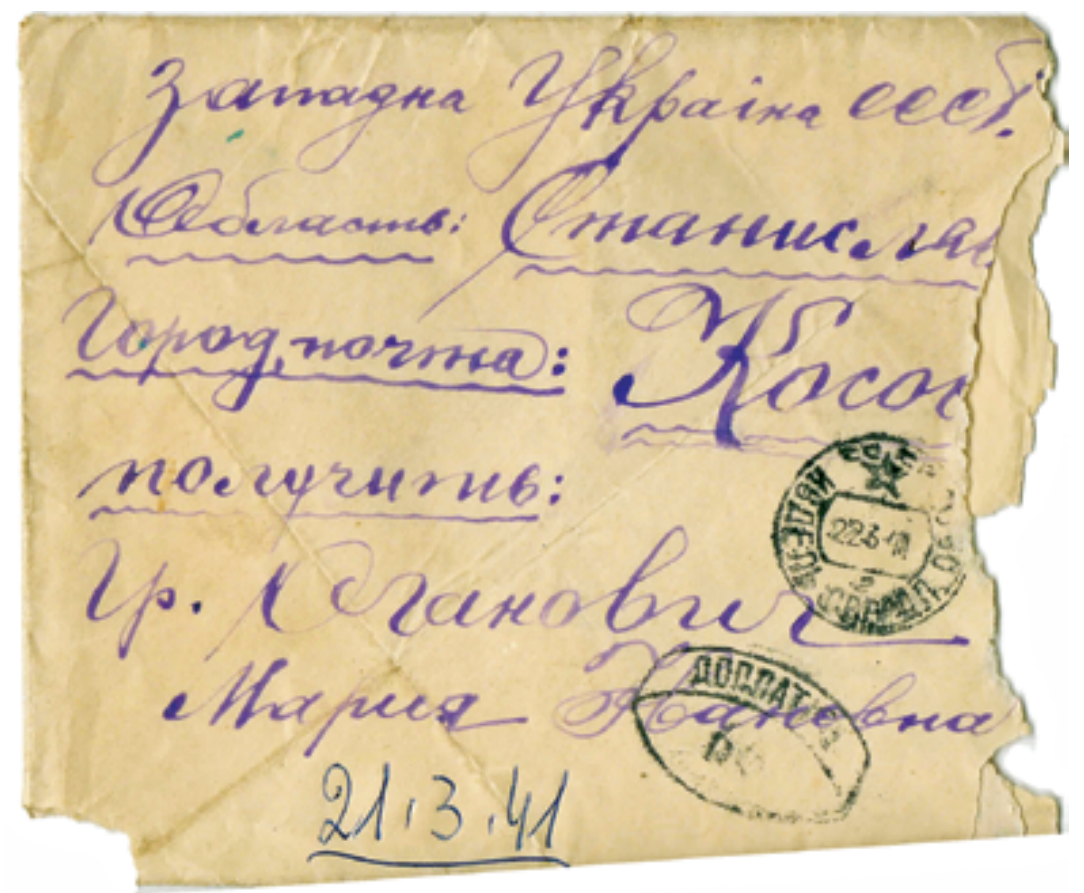

Każdy skrawek papieru służył za papeterię. Listy Issaka Donigiewicza z łagru, Fundacja Kultury i Dziedzictwa Ormian Polskich w Warszawie

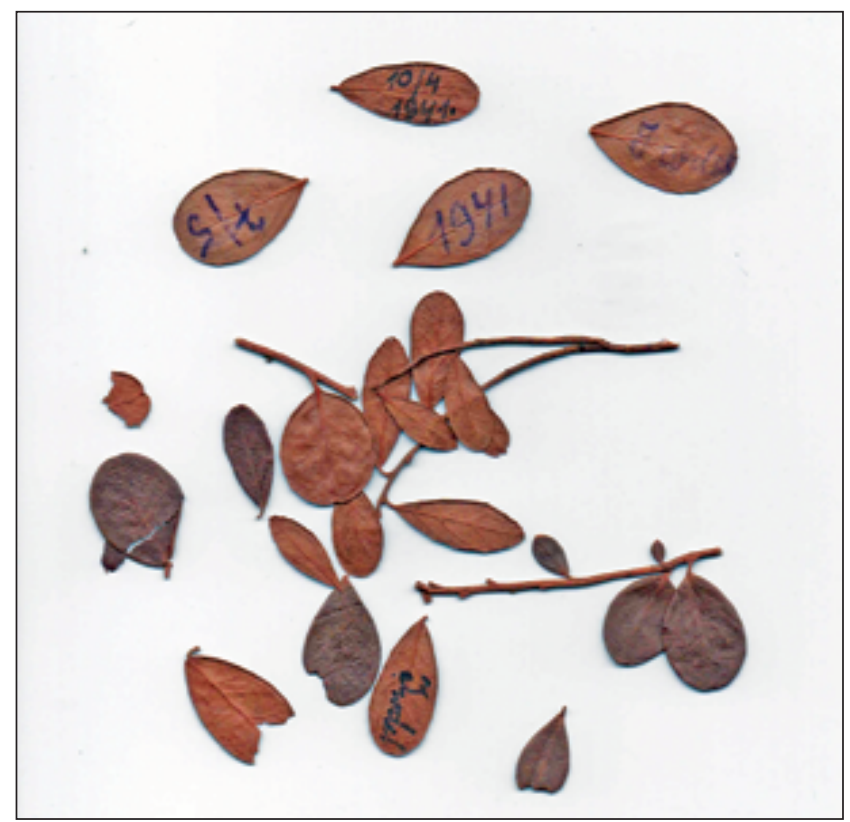

Listki z okolic łagru w Iwdelu przesłane córkom przez Issaka Donigiewicza, zbiory rodzinne 